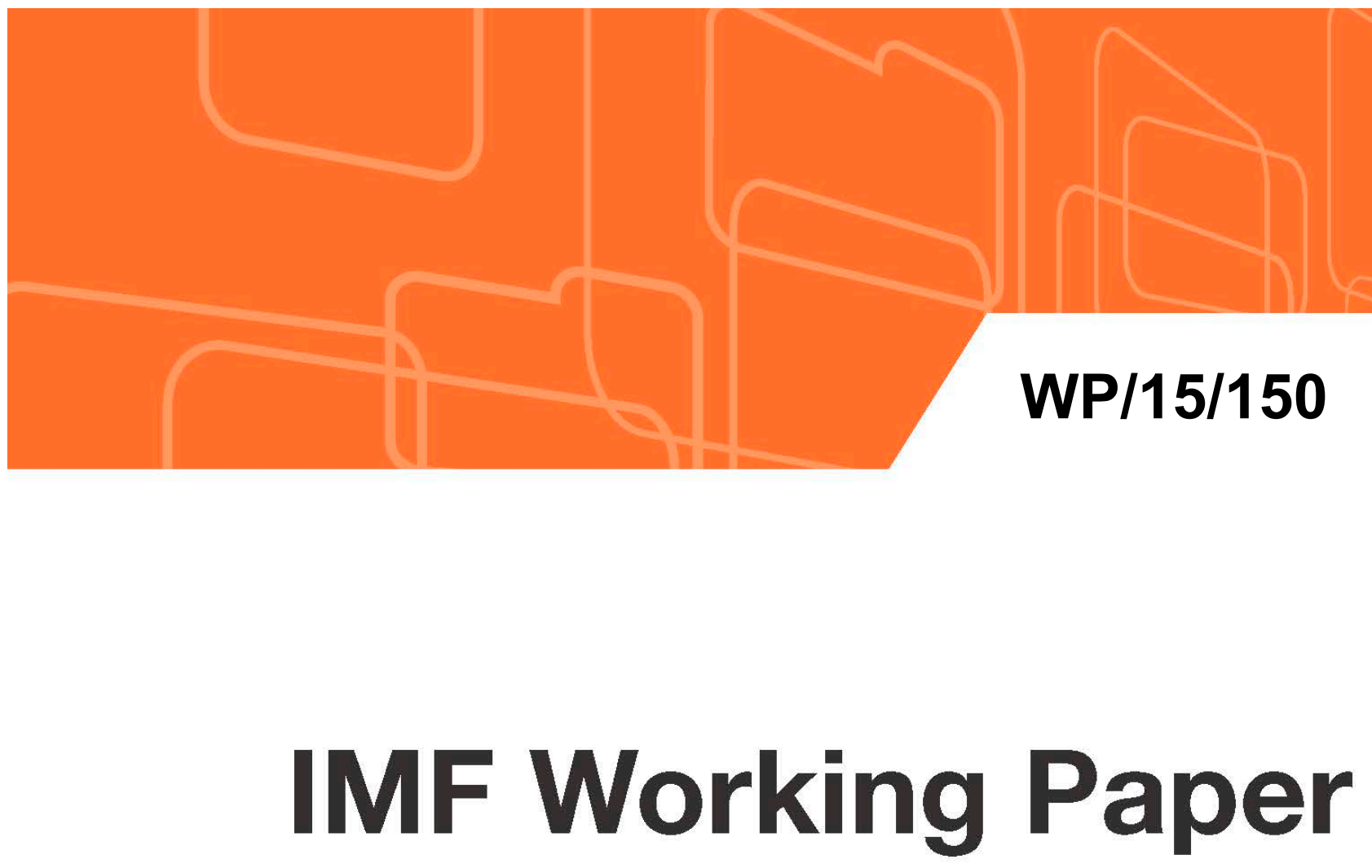

\title{
Banks in The Global Integrated Monetary and Fiscal Model
}

by Michal Andrle, Michael Kumhof, Douglas Laxton, and Dirk Muir

IMF Working Papers describe research in progress by the author(s) and are published to elicit comments and to encourage debate. The views expressed in IMF Working Papers are those of the author(s) and do not necessarily represent the views of the IMF, its Executive Board, or IMF management.
I $N$
$N T E R$
N A T | O N A L
M O N E T A R Y
$F \cup \mathbb{N}$ 


\title{
IMF Working Paper
}

Research Department

Banks in The Global Integrated Monetary and Fiscal Model

Prepared by Michal Andrle, Michael Kumhof, Douglas Laxton and Dirk Muir

Authorized for distribution by Olivier Blanchard

July 2015

IMF Working Papers describe research in progress by the author(s) and are published to elicit comments and to encourage debate. The views expressed in IMF Working Papers are those of the author(s) and do not necessarily represent the views of the IMF, its Executive Board, or IMF management.

\begin{abstract}
The Global Integrated Monetary and Fiscal model (GIMF) is a multi-region DSGE model developed by the Economic Modeling Division of the IMF for policy and scenario analysis. This paper compares two versions of GIMF, GIMF with a conventional financial accelerator, where bank balance sheets do not play a prominent role, and GIMF with both a financial accelerator and a fully specified banking sector that can make lending losses, and that is regulated according to Basel-III. We illustrate the comparative macroeconomic properties of both models by presenting their responses to a wide range of fiscal, demand, supply and financial shocks.
\end{abstract}

JEL Classification Numbers: E62, H21,H39, H63

Keywords: Multi-Region DSGE Models, Financial Accelerator, Macro-Financial Linkages, Macroprudential Policy

Author's E-Mail Address: mandrle@,imf.org; mkumhof@imf.org; dlaxton@,imf.org; dmuir@,imf.org 


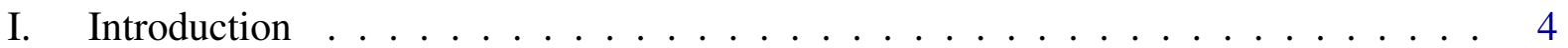

II. The Global Integrated Monetary and Fiscal Model (GIMF) . . . . . . . . . . . 5

A. Household Sector . . . . . . . . . . . . . . . . . . 6

B. Production Sector . . . . . . . . . . . . . . . . 7

C. Financial Sector . . . . . . . . . . . . . . . . . . 7

1. Banks in GIMF-BGG . . . . . . . . . . . . . . . . 8

2. Banks in GIMF-BANKS .................. . . . 8

D. International Dimensions . . . . . . . . . . . . . . . . 11

E. Fiscal and Monetary Policy . . . . . . . . . . . . . . . 11

III. Properties of Fiscal Stimulus Shocks . . . . . . . . . . . . . . . . . . 12

A. Two-Year Increase in Government Consumption or Government Investment . . 12

B. Two-Year Increase in General or Targeted Lump-sum Transfers . . . . . . . . . 14

C. Two-Year Decrease in Taxation . . . . . . . . . . . . . . . 15

IV. Properties of Demand Shocks . . . . . . . . . . . . . . . . . 16

A. Temporary Increase in the Policy Rate . . . . . . . . . . . . . . . . . . . . . . . .

B. Temporary Increase in Private Domestic Demand . . . . . . . . . . . . 17

V. Properties of Supply Shocks . . . . . . . . . . . . . . . . . . . . 18

A. Productivity Shocks . . . . . . . . . . . . . . . . . 18

1. Permanent Increase in the Level of Productivity . . . . . . . . . . . . 18

2. Persistent Increase in the Growth Rate of Productivity . . . . . . . . . . 18

B. Permanent Drop in Wage Markups . . . . . . . . . . . . . . . . . . 19

C. Permanent Drop in Price Markups . . . . . . . . . . . . . . . . . . 20

D. Permanent Increase in Tariffs . . . . . . . . . . . . . . . . . . . 20

VI. Properties of Financial Sector Shocks . . . . . . . . . . . . . . . . . . . 21

A. Temporary Increase in Borrower Riskiness . . . . . . . . . . . . . . . . 21

1. Equal Impact Effect on External Financing Spread . . . . . . . . . . . . 21

2. Equal Size of Shock to Borrower Riskiness . . . . . . . . . . . . . . 23

B. Shocks to Macroprudential Policy Settings in GIMF-BANKS . . . . . . . . . . 23

1. Fixed versus Countercyclical MCAR . . . . . . . . . . . . . 23

2. Immediate versus Gradual Increase in MCAR . . . . . . . . . . . . . 24

VII. Conclusion . . . . . . . . . . . . . . . . . . . 25

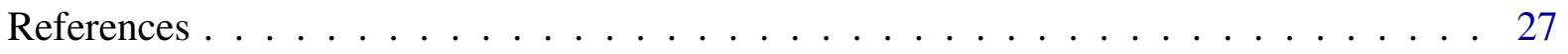

Tables 
Figures

1. Temporary Stimulus Through Government Consumption (1pc of GDP for 2 years) . 29

2. Temporary Stimulus Through Government Investment (1pc of GDP for 2 years) . . 30

3. Temporary Stimulus Through Government Consumption - Bank Loan Losses . . . . 31

4. Temporary Stimulus Through Targeted Transfers (1pc of GDP for 2 years) . . . . . 32

5. Temporary Stimulus Through General Transfers (1pc of GDP for 2 years) . . . . . . 33

6. Temporary Stimulus Through Lower Consumption Taxes (1pc of GDP for 2 years) . 34

7. Temporary Stimulus Through Lower Labor Income Taxes (1pc of GDP for 2 years) 35

8. Temporary Stimulus Through Lower Capital Income Taxes (1pc of GDP for 2 years) 36

9. Temporary Increase in the Policy Rate . . . . . . . . . . . . . . . . . 37

10. Temporary Increase in Private Domestic Demand . . . . . . . . . . . . . . . . 38

11. Permanent Increase in Labor Productivity . . . . . . . . . . . . . . . . . . . . . 39

12. Ten-Year Increase in Labor Productivity Growth . . . . . . . . . . . . . . . . 40

13. Permanent Drop in Wage Markup . . . . . . . . . . . . . . . . . . . . . 41

14. Permanent Drop in Price Markup . . . . . . . . . . . . . . . . . . . . . 42

15. Permanent Increase in Tariffs . . . . . . . . . . . . . . . . . . . . . 43

16. Temporary Increase in Borrower Riskiness - Equal External Financing Spreads . . . 44

17. Temporary Increase in Borrower Riskiness - Bank Loan Losses . . . . . . . . . . 45

18. Temporary Increase in Borrower Riskiness - Equal Shock Sizes . . . . . . . . . . 46

19. Fixed versus Countercyclical MCAR . . . . . . . . . . . . . . . . 47

20. Immediate versus Gradual Increase in MCAR . . . . . . . . . . . . . 48 


\section{INTRODUCTION}

This paper documents the comparative simulation properties of two versions of the International Monetary Fund's Global Integrated Monetary and Fiscal Model (GIMF). The first version is the original GIMF, with a conventional financial accelerator mechanism that follows Bernanke, Gertler, and Gilchrist (1999) and Christiano, Motto, and Rostagno (2014). The theory of this model, which we will refer to as GIMF-BGG, is documented in Kumhof and others (2010), and its simulation properties in Anderson and others (2013). In this model banks, because they write state-contingent lending contracts with their borrowers, make zero profits in all states of the world, and therefore do not require equity to protect their depositors against adverse shocks. Therefore, while banks determine the lending spread faced by borrowers, bank equity and bank balance sheets play no meaningful role. The second version of GIMF, which we will refer to as GIMF-BANKS, is identical to GIMF-BGG in all but the specification of the banking sector. The theory underlying the banking sector is documented in Benes and Kumhof (2011). In this model, banks fix their lending rates one period ahead of the repayment due-date of the loan, and therefore generally make profits or losses when the economy experiences macroeconomic shocks. Because banks also face regulatory constraints that represent Basel-III capital-adequacy regulations, bank equity assumes a critical role as a shock absorber, and bank balance sheets become an essential part of the model.

In most of this paper we will compare the GIMF-BGG simulations of Anderson and others (2013) to the corresponding GIMF-BANKS simulations. For a consistent comparison of the two models, the paper opts for identical country coverage and calibration as in Anderson and others (2013), with the exception of the banking sector. The properties of both models are illustrated by showing the response of key macroeconomic variables to different shocks. The focus is on the response of U.S. macroeconomic variables to U.S. shocks, because spillovers to other regions of the world are small, and more importantly exhibit only small differences between GIMF-BGG and GIMF-BANKS. The reader who is interested in spillover properties is therefore referred to Anderson and others (2013) for more details. The qualitative properties that we show for the U.S. response to U.S. shocks will in general also hold for the response of other regions to shocks originating in those regions, but with some differences that result from special features in each region, such as different degrees of trade openness, different shares of liquidity-constrained households in the population, or different exchange rate regimes.

Section II contains a short description of GIMF-BGG and GIMF-BANKS, which summarizes Kumhof and others (2010) and Benes and Kumhof (2011). Sections III through VI explore the response of the two models to different types of shocks, specifically fiscal stimulus shocks, aggregate demand shocks, aggregate supply shocks, and financial sector shocks. Section VII concludes. 


\section{The Global Integrated Monetary and Fiscal Model (GiMf)}

GIMF is a multicountry Dynamic Stochastic General Equilibrium (DSGE) model with optimizing behavior by households and firms, and full intertemporal stock-flow accounting. There are frictions in the form of nominal rigidities in prices and wages, and real rigidities in consumption, investment and imports. Households exhibit non-Ricardian behavior, with finite planning horizons among one group of households, and liquidity constraints among the remaining group of households.

The assumption of finite planning horizons ${ }^{1}$ distinguishes GIMF from standard monetary DSGE models. It implies that steady state net-foreign-asset positions and the steady state world real interest rate are endogenously determined by variables that include not only preferences but also the level of government debt and and structure of taxation (distortionary capital taxes, for instance). Finite planning horizons together with liquidity constraints generate nonRicardian behavior in response to both spending-based and revenue-based fiscal measures, which makes the model particularly suitable to analyze fiscal policy questions. ${ }^{2}$

Asset markets are incomplete in GIMF. All financial contracts last one period. Government debt and bank deposits are only held domestically, are denominated in domestic currency, and are non-contingent. The only assets traded internationally are non-contingent bonds denominated in U.S. dollars. Firms are owned domestically, and firm equity is not traded in domestic financial markets. Instead, households receive lump-sum dividend payments.

Firms employ capital and labor to produce tradable and nontradable intermediate goods. A financial accelerator mechanism based on Bernanke, Gertler, and Gilchrist (1999) is operative. When banks take over defaulting firms and liquidate their capital, they can only do so at a discount. This implies that banks' lending rate includes an external financing premium, which varies directly with the leverage (debt-to-equity) ratio of borrowers. Beyond this, there are important differences between the financial sectors in GIMF-BGG and GIMF-BANKS that will be discussed in more detail in Section II.C below.

GIMF features multiple regions that encompass the entire world economy. All bilateral trade flows, and the associated relative prices for each region, are explicitly modeled. The version used in this paper comprises 5 regions: the United States, the euro area, Japan, emerging Asia (including China), and, as a single entity, remaining countries.

\footnotetext{
${ }^{1}$ See Blanchard (1985) for the basic theoretical building blocks, and Kumhof and Laxton (2007, 2013) for analyses of the fiscal policy implications.

${ }^{2}$ Coenen and others (2012) show that GIMF fiscal multipliers for temporary shocks are similar to those of standard monetary business cycle models.
} 


\section{A. Household Sector}

There are two types of households, who both consume goods and supply labor. Overlappinggenerations (OLG) households smooth consumption over their expected remaining lifetime, or planning horizon, of 20 years, by borrowing and lending in domestic and international credit markets. By contrast, liquidity-constrained (LIQ) households have no access to credit markets, and therefore consume their disposable income in every period. Households pay direct taxes on labor income, indirect taxes on consumption spending, and a lump-sum tax, and receive government transfers that are either paid to all households equally, or targeted specifically to LIQ households.

OLG households save by acquiring domestic government bonds, international U.S. dollar bonds, and deposits in domestic banks. They maximize their lifetime utility subject to their intertemporal budget constraint. Aggregate OLG consumption is a function of financial wealth and of the present discounted value of after-tax income. The consumption of LIQ households, which are often referred to as rule-of-thumb households in the literature, is equal to their current net income, so that their marginal propensity to consume out of current income is close to unity. ${ }^{3}$ A high proportion of LIQ households in the population therefore implies significant fiscal multipliers from temporary changes to taxes and transfer payments.

For OLG households with finite-planning horizons, a tax cut has a short-run positive effect on demand. Even when the cut is matched with a tax increase in the future that leaves government debt unchanged in the long run, the short-run impact remains positive, as the change will tilt the time profile of consumption toward the present. In effect, OLG households discount future tax liabilities at a higher rate than the market rate of interest. Thus, an increase in government debt today represents an increase in their wealth, because a share of the resulting higher future taxes is payable beyond their planning horizon. If the increase in government debt is permanent, with tax rates rising sufficiently in the long run to stabilize the debt-toGDP ratio at higher total interest payments, this will raise real interest rates, and crowd out both real private capital and net foreign assets.

Increases in the real interest rate have a negative effect on consumption, mainly through their impact on the discount rate in the expressions for household wealth. Households' intertemporal elasticity of substitution in consumption determines the magnitude of the long-run crowding-out effects of government debt, since it determines the extent to which real interest rates have to rise to encourage households to provide the required savings.

\footnotetext{
${ }^{3}$ It is not exactly equal to unity due to the presence of consumption taxes.
} 


\section{B. Production Sector}

Firms, which produce tradable and nontradable intermediate goods, are managed in accordance with the preferences of their owners, OLG households. They therefore also have finite planning horizons. The main substantive implication of this assumption is the presence of a substantial equity premium driven by impatience. Firms are subject to real rigidities in labor hiring and investment. They operate in monopolistically competitive output markets, and thus goods prices contain a markup over marginal cost. Goods prices and wages exhibit nominal rigidities. Exports are priced to the local destination market, and imports are subject to quantity adjustment costs. Firms pay capital income taxes to the government, wages and economic profits (mostly due to markups) to households, and the return to capital to entrepreneurs, who supply the capital.

Entrepreneurs borrow from banks because their retained earnings do not fully finance investment. If their earnings fall below the minimum required to make the contracted interest payments, banks take over the entrepreneur's capital stock, and realize its value after deducting bankruptcy monitoring costs.

Final output is produced using public infrastructure (the government capital stock) as an input, in combination with tradable and nontradable intermediate goods. Therefore, government capital adds to the productivity of the economy.

\section{Financial Sector}

GIMF contains a limited menu of financial assets. Government debt and bank loans are noncontingent, are denominated in domestic currency, and are not tradable across borders. OLG households may, however, issue or purchase internationally tradable U.S.-dollar-denominated obligations. Unlike in Goodhart and others (2012), debt contract maturity is one period and no maturity mismatch exists on banks' balance sheets in the model. Firms do not issue tradable equity, but rather pay out their after-tax cash flow in a lump-sum fashion. Banks provide loans only to entrepreneurs in the home country, for direct spillover implications of global banks, see Kollmann (2013) or Fecht, Grüner, and Hartmann (2012). Neither version of GIMF features an explicit housing market and housing loans, as in Gurrieri and Iacoviello (2013), for instance. 


\section{Banks in GIMF-BGG}

Following Bernanke, Gertler, and Gilchrist (1999), banks write state-contingent lending contracts, which ensure zero profits in each state of nature. ${ }^{4}$ This means that no equity, and no macro-prudential regulation, are required to protect banks and the wider economy from vulnerabilities in the banking sector. With zero equity, bank loans equal bank deposits. Balance sheet problems can therefore only arise among banks' borrowers, entrepreneurs. Banks' role is solely to price loans to accurately reflect lending risk, with an optimality condition whereby the spread between the interest rate paid by borrowers and the risk-free rate increases with the leverage of borrowers. The reason is that with high leverage, borrowers have less "skin in the game", so that negative payoffs to lenders in the event of borrower bankruptcy are larger. Higher average lending rates are therefore needed to guarantee zero profits. For a discussion of technical details of the GIMF-BGG, see Kumhof and others (2010).

\section{Banks in GIMF-BANKS}

The GIMF-BANKS model follows the model by Benes and Kumhof (2011). In contrast to Bernanke, Gertler, and Gilchrist (1999), Christiano, Motto, and Rostagno (2014), or Curdia and Woodford (2010), the banks have their own non-zero net worth and are exposed to nondiversifiable aggregate risk determined endogenously on the basis of optimal standard nominal debt contract. The absence of net worth changes would preclude an analysis of macroprudential capital-adequacy regulation of bank balance sheets.

Changes in the net worth of banks result mainly from unexpected profit or loss due to the standard nominal debt contract, which is an important deviation from the standard BGG setup often found in the literature. The ex-ante contracted interest rate between the bank and the borrower is not state-contingent and cannot be re-set later, for the bank to break even. As a consequence, an unexpected change in the economy's fundamentals results either in profit or loss for the bank, impacting its net worth.

The critical factor in determining bank's choice of capital structure is capital-adequacy regulation. Banks operate under limited liability for its shareholders and hold equity to protect themselves against the penalties that become due to the regulator (government), should banks violate capital-adequacy requirements. The capital regulation is not based on a hard-wired capital ratio, as in Angeloni and Faia (2009), for instance. Rather, regulation is viewed as a system of penalties imposed on banks in case they fall below the regulatory minimum. Such penalties then create behavioral incentives for banks to choose endogenous regulatory capital buffers under uncertainty, an idea first advocated by Milne (2002).

\footnotetext{
${ }^{4}$ We emphasize that state-contingent lending contracts have more in common with banks taking an equity stake in firms than with real-world lending, where banks' payoff is invariant to the state of the world except when borrowers default.
} 
In the model, Basel-III-style minimum capital-adequacy ratio (MCAR) regulations stipulate that banks which do not maintain a minimum level of equity equal to 8 percent of total assets must pay a penalty equal to a certain fraction of their assets. Banks trade off the cost of having to pay this penalty in the event of unfavorable shocks against the cost of maintaining even higher levels of equity. The model is calibrated so that in equilibrium banks maintain even higher levels of equity equal to 10.5 percent of total assets, which is the value consistent with Basel-III regulation ( 8 percent minimum with 2.5 percent of assets as a capital buffer). In addition, Basel-III allows for a countercyclical capital buffer that can vary over the business cycle, which is also incorporated as an option into the model.

In order to make the model tractable, the banking sector is modeled as if composed of retail and wholesale banks. Retail banks, or branches, write nominal debt contracts with entrepreneurs and obtain financing from the wholesale banks, or branches. Any profit or loss of retail banks is transferred to wholesale banks. The wholesale banks face the capital regulation penalty and choose the wholesale rate, the cost of funds for the retail banks. Thus, there is a continuum of wholesale banks, each of which is exposed to idiosyncratic shocks, implying a distribution of capital adequacy ratios across banks. Only a fraction of banks has to pay penalties in each period. For detailed account of the banking sector derivations and modeling choices, see Benes and Kumhof (2011).

In GIMF-BANKS, with positive bank equity, bank liabilities equal bank deposits plus bank equity, and balance sheet problems can simultaneously occur on the balance sheets of banks and their borrowers. As in GIMF-BGG, banks still have the role of pricing loans accurately to reflect lending risk, with a spread between the interest rate paid by borrowers and the riskfree rate that increases in the leverage of borrowers. However, in GIMF-BANKS the spread between the interest rate paid by firms (retail rate) and the risk-free rate is composed of two parts - the external financing spread and the wholesale spread. The external financing spread (retail rate versus wholesale-bank rate) reflects the riskiness of the borrower for a given leverage in the banking sector. The wholesale spread (wholesale-bank rate versus risk-free rate) is increasing in the banks' leverage as higher leverage increases the probability of breaching Basel III capital-adequacy requirement, which is penalized by regulatory authority.

Four banking sector variables are reported in the figures of this paper. The first is the percent deviation from steady state of bank loans. The second is the Basel-III capital-adequacy ratio, measured in percentage points of total assets. The other two banking sector variables are interest rate spreads, reported as percentage point differences between ex-ante rates.

The wholesale lending spread is the difference between the wholesale lending rate, meaning the rate which banks would charge to a notional riskless borrower (such borrowers are in fact not present in the model), and the rate at which banks fund themselves, which in GIMF is the policy rate. In GIMF-BGG this spread is always identically equal to zero, because in that model banks cannot make losses, do not maintain equity, and are not subject to capitaladequacy regulations. In GIMF-BANKS this spread is positive in the steady state, and reflects 
both the likelihood that bank equity drops below the MCAR and the size of the regulatory penalty that becomes payable if this happens. Furthermore, variations in the wholesale lending spread become an important part of the macroeconomic adjustment mechanism in GIMFBANKS.

The external financing spread is the difference between the retail lending rate, meaning the rate which banks charge to risky borrowers, and the wholesale lending rate. In GIMF-BGG the retail lending rate is state-contingent, the wholesale lending rate is the policy rate, and the spread reported in the figures represents the expected retail lending rate minus the wholesale lending rate. In GIMF-BANKS both the retail and wholesale lending rates are not statecontingent.

The external financing spread needs to be carefully distinguished from the external financing premium of Bernanke, Gertler, and Gilchrist (1999) and the subsequent literature. The external financing premium equals the spread over the wholesale lending rate of an average return over all loans, including the interest received on loans that do not default and the recovery value of the capital seized from firms that do default. Monitoring costs drive a wedge between the previous going-concern value of the capital before bankruptcy and the recovery value after bankruptcy. In the steady state this necessitates a positive external financing premium that is exactly equal to the recovery losses as a percentage of the value of assets. This notion of the external financing premium, rather than the external financing spread, has predominated in the financial accelerator literature, although unlike the external financing spread it does not have a clearly identifiable counterpart in the data. We have used this variable to ensure backward compatibility of the steady states of GIMF-BGG and GIMF-BANKS. Specifically, we have calibrated GIMF-BANKS in such a way that the steady state external financing premium is identical to that used in the calibration of GIMF-BGG in Anderson and others (2013).

The model equations and calibration of GIMF-BGG and GIMF-BANKS are mostly identical, except, of course, for the banking sector, where there are four key differences. First, in GIMF-BGG the zero profit condition of banks has to hold in all states of the world, while in GIMF-BANKS it only has to hold ex ante, with shock realizations generally implying profits or losses. Second, in GIMF-BANKS loans equal deposits plus equity, while in GIMF-BGG loans equal deposits. Third, in GIMF-BANKS bank equity becomes a new state variable with an accumulation equation. This implies that, similar to the effects of equity on borrower balance sheets, banks become the source of an additional financial accelerator mechanism. Fourth, in GIMF-BGG the lending rate to a notional riskless borrower equals the policy rate, while in GIMF-BANKS the lending rate to the same notional riskless borrower equals the policy rate plus a spread that reflects the cost associated with Basel III regulatory requirements.

In terms of calibration, the equity of entrepreneurs is calibrated to be identical in GIMF-BGG and GIMF-BANKS, at 66 percent of GDP. Bank equity in GIMF-BGG is zero, but it is pos- 
itive, at 7 percent of GDP, in GIMF-BANKS. In GIMF-BANKS there is therefore additional risk-bearing equity in the economy that can help to absorb macroeconomic shocks.

\section{International Dimensions}

All bilateral trade flows, and the corresponding prices and exchange rates, are explicitly modeled in GIMF. Trade flows include exports and imports of both intermediate and final goods, and are calibrated in steady state to match the bilateral flows observed in recent data. Because of households' finite planning horizons, steady-state net-foreign-asset positions, and the steadystate world real interest rate, are determined by the interaction of global saving and investment decisions.

\section{E. Fiscal and Monetary Policy}

Fiscal policy is conducted using a variety of expenditure and tax instruments. Government spending may take the form of consumption or investment ${ }^{5}$ spending on goods and services, or of lump-sum transfers, made either to all households or targeted towards LIQ households. Revenue accrues from taxes on labor income and capital income, consumption taxes, lumpsum taxes, and tariffs on imported goods.

The fiscal policy rule ensures that in the long run the government debt-to-GDP ratio converges to its target level, while in the short run countercyclical fiscal policy, representing automatic stabilizers, is in effect. The rule is implemented through changes in general transfers, but this can be replaced with other tax, transfer or spending instruments if that is considered more realistic for a specific region.

The inflation-forecast-based interest rate reaction function of monetary policy varies the gap between the actual policy rate and the long-run equilibrium rate to achieve a stable target rate of inflation over time. In the simulations reported in this paper, monetary policy is assumed to operate normally, without constraints due to the zero lower bound on nominal interest rates.

\footnotetext{
${ }^{5}$ Government investment spending augments a public capital stock that enters the economy's aggregate technology. This capital stock depreciates at a fixed rate over time.
} 


\section{Properties of Fiscal Stimulus Shocks}

This section studies the simulation properties of GIMF-BGG and GIMF-BANKS in response to changes in the seven fiscal instruments in GIMF - government consumption, government investment, general lump-sum transfers, lump-sum transfers targeted to LIQ households, and taxes on private consumption, labor income and capital income. The simulation experiments are conducted in the United States block of the model. Unlike in Anderson and others (2013), we will limit the policy experiments to temporary fiscal stimulus measures, specifically to fiscal stimulus that expires after two years, while omitting simulations of permanent fiscal consolidations. The reason is that for fiscal policy shocks the differences between the two variants of GIMF are invariably small, and the simulations of temporary measures are sufficient to demonstrate that. For the simulations of permanent measures the reader is therefore referred to Anderson and others (2013) for details. In this and all following subsections, results are reported in terms of deviations from the steady-state baseline.

\section{A. Two-Year Increase in Government Consumption or Government Investment}

Figures 1 and 2 compare the effects of increasing either U.S. government consumption or U.S. government investment by 1 percentage point of baseline GDP for two years. The increase in government consumption drives up real GDP by slightly less than 1 percent for two years, while headline inflation rises by around a quarter of one percentage point. When the same stimulus measure is performed through government investment, real GDP increases by just over 1 percent after two years, and thereafter stays above baseline for an extended period, with inflation effects similar to the case of government consumption.

Under both types of stimulus, higher government spending increases aggregate demand directly. Since government goods are assumed to be produced using both domestic and imported inputs, there are notable effects in both the domestic and external sectors. The increase in demand for domestic goods increases marginal cost and prices of domestic goods. In response to rising inflation, the U.S. monetary authority increases the nominal policy interest rate. This leads to higher real interest rates, which increase the cost of capital, thereby dampening private investment demand and partly offsetting the expansionary effect of the stimulus measure. Higher real interest rates also reduce the present discounted value of future incomes, in other words consumer wealth, which works to offset the impact of higher incomes on consumption expenditure. Fiscal policy also operates in a countercyclical fashion. Specifically, automatic fiscal stabilizers operate such that transfers adjust to dampen private demand, especially demand of LIQ households whose current consumption moves with their current income almost one-forone. The increase in real interest rates appreciates the U.S. real effective exchange rate. As a result, the trade balance temporarily deteriorates. 
What differentiates an increase in government investment from that of an increase in government consumption is the additional stimulative effect of government investment on the government capital stock, which positively affects private sector aggregate productivity and real GDP. The resulting positive productivity and wealth effects account for the much stronger responses of both investment and consumption.

The differences between GIMF-BGG and GIMF-BANKS in these simulations have their origin in the fact that banks in GIMF-BANKS can make net lending gains or losses that change their capital-adequacy ratio, while in GIMF-BGG banks make no net lending gains or losses. Specifically, in GIMF-BANKS the capital-adequacy ratio changes by between 0.25 and 0.30 percentage points of total assets in Figures 1 and 2. The reason for the improvement of the capital-adequacy ratio in GIMF-BANKS is that the increase in demand triggered by fiscal stimulus leads to above-average returns to lending at the previously set lending rate. This permits a 7-9 basis points reduction of the wholesale lending spread, which reflects the state of banks' balance sheets. This, by feeding through to the final lending rate, stimulates investment activity. The overall effect, however, is small, because its aggregate demand implications are limited to investment, and because even the differences in investment performance are not dramatic. As a result, the behavior of GDP under GIMF-BGG and GIMF-BANKS is very similar.

An additional reason for the small size of the overall effect is the behavior of the external financing spread, which reflects the state of borrowers' balance sheets. Changes in the external financing spread partly (but not completely) offset changes in the wholesale lending spread, so that the drop in the overall lending spread is smaller than the drop in the wholesale lending spread. We will encounter this for several other shocks below. The reason is that the fundamentals of credit demand in these two models are virtually identical, because the initial state of bank borrowers is calibrated to be identical across the two models. The market clearing lending rate is determined by the interplay between credit demand and credit supply. When the wholesale lending spread drops, the required drop in the external financing spread is relatively lower in GIMF-BANKS than in GIMF-BGG to clear the loan market, to attain essentially identical retail rate level.

Figure 3 turns to the question of why the increase in demand triggered by fiscal stimulus leads to above-average returns to lending at the previously set lending rate. To study this question we need to examine the expression of bank loan losses $\check{\Lambda}_{t}^{\ell}$ in GIMF: ${ }^{6}$

$$
\check{\Lambda}_{t}^{\ell} x=r_{\ell, t} \check{\ell}_{t-1}-q_{t-1} \check{k}_{t-1} r e t_{k, t} \gamma_{t} .
$$

In period $t-1$, retail lending banks borrowed the funds they lent to entrepreneurs, $\check{\ell}_{t-1}$, at the nominal wholesale lending rate $i_{\ell, t-1}$. Their real ex-post cost of these funds in period $t$ equals $\check{\ell}_{t-1}$ multiplied by the real wholesale lending rate $r_{\ell, t}=i_{\ell, t-1} / \pi_{t}$, where $\pi_{t}$ is headline

\footnotetext{
${ }^{6}$ An inverted hat above a variable indicates normalization by aggregate productivity. The term $x$ is the economy's steady state growth rate of productivity. It has no material implications for our analysis.
} 
inflation. Therefore, if time $t$ inflation is higher than expected at the time of contracting the loan, banks' real loan losses will, ceteris paribus, be lower.

The second part of loan losses represents banks' share $\gamma_{t}$ in the return on the capital put in

place by their borrowers in the previous period, $q_{t-1} \breve{k}_{t-1} r e t_{k, t}$, where $q_{t-1} \breve{k}_{t-1}$ is the time $t-1$ market value of physical capital $\breve{k}_{t-1}$, while ret $_{k, t}$ is the financial return on capital between periods $t-1$ and $t$. The latter includes depreciation adjusted capital gains, the user cost of capital, and the effects of capital income taxes. Because $q_{t-1} \check{k}_{t-1}$ is predetermined, the two determinants of bank loan losses in this expression are the financial return to capital and banks' share in that return. Ceteris paribus, a larger than expected financial return to capital reduces banks' loan losses, and so does an increase in banks' share in that return.

Figure 3 shows a decomposition of the terms in (1) for the stimulus based on government spending of Figure 1. Variables with an overbar denote the steady-state value of the variable, to help visualise the decomposition of the loan losses evolution. Our focus is exclusively on period 1, the period when the shock hits. This is because profits in all subsequent periods have to equal zero, as banks can, following the initial shock, adjust their lending rates to take account of the shock. We begin with banks' share in the return to capital which, strikingly, remains almost completely unchanged on impact. The increase in aggregate demand does of course lead to a significantly higher financial return to capital, but this is almost exactly offset by a reduction in banks' share in that return. The reason is the limited liability of banks' borrowers, which means that borrowers and not banks are the residual claimants on the returns to capital. Firms are more profitable but due to the structure of the nominal debt contract they repay only what has been agreed. The upside comes from less firms going bankrupt than anticipated. On the funding side, positive inflation surprise redistributes resources from depositors to lenders.

We will not repeat the detailed analysis of Figure 3 for all but one of the remaining shocks studied in this paper. The reason is that for most other shocks the pattern displayed in Figure 3 is repeated. The exception is shocks to borrower riskiness, which will be studied in Section VI.

\section{B. Two-Year Increase in General or Targeted Lump-sum Transfers}

Figures 4 and 5 show the effects of an increase in U.S. lump-sum transfers by 1 percentage point of baseline GDP for two years, either targeted to only LIQ households (Figure 4) or paid equally to all households (Figure 5). Transfers do not feed into aggregate demand directly, but indirectly through the effect of household incomes on household spending. The increase in general transfers is split between OLG households and LIQ households, based on their calibrated share of the total U.S. population ( $75 \%$ and $25 \%$, respectively). 
When targeted lump-sum transfers are increased, real GDP increases by around 0.4 percent, while inflation rises by around 0.15 percentage points. When general lump-sum transfers are increased, the increases in real GDP and inflation equal only around one quarter of those magnitudes.

When temporarily higher transfers are directed only to LIQ households (Figure 4), there is a larger immediate increase in private consumption and aggregate demand, mainly because LIQ households spend all of their current income. The increase in aggregate demand puts upward pressure on inflation, with the monetary policy response driving up real interest rates. The increase in real interest rates, which is considerably more persistent than the fiscal stimulus, due to inflation persistence and central bank interest rate smoothing, puts downward pressure on private investment, which declines as soon as the stimulus expires. Higher interest rates, by increasing the rate at which OLG households discount future incomes, also partly offset the impact of higher household incomes on private consumption. In addition, automatic fiscal stabilizers reduce transfers during the upturn, again partly offsetting the boost to private demand. These factors in combination lead to a fiscal multiplier well below unity, at around 0.4. The increase in real interest rates appreciates the U.S. real effective exchange rate and leads to a temporary deterioration in the trade balance.

When the temporary increase in transfers is paid equally to all households (Figure 5), the effects are qualitatively similar, but much smaller, since OLG households can smooth their consumption using their access to capital markets. Thus the boost to private consumption, and to aggregate demand, is primarily driven by the transfers to LIQ households, whose increase in income is only one quarter of the case of targeted transfers.

The differences between GIMF-BGG and GIMF-BANKS are, again, quantitatively small.

\section{Two-Year Decrease in Taxation}

Figures 6, 7 and 8 compare the effects of a reduction in taxation equal to 1 percent of baseline GDP for 2 years, using either consumption taxes, labor income taxes or capital income taxes. All of these tax cuts produce modest GDP gains of $0.25-0.30$ percent.

The three different taxes have different transmission channels. Consumption and labor income tax cuts primarily affect households. Since these tax cuts are temporary, their demand effects are primarily due to LIQ households. But because they also have beneficial supply side effects, by removing distortions, their GDP effects lie between those of targeted and untargeted lumpsum transfers. Finally, capital income tax cuts primarily affect firms.

Lower consumption taxes (Figure 6) directly decrease the price that households pay for consumption goods. On the supply side, this reduces the gap between the real wage and the marginal rate of substitution between consumption and leisure, so that households are willing to 
increase their labor supply. On the demand side, lower after-tax prices of consumption goods and higher labor supply lead to higher incomes and private consumption for the two years of the stimulus. The increase in demand leads to a small increase in CPI inflation (excluding indirect taxes), and thereby of nominal and real interest rates.

Lower labor income taxes (Figure 7) work in a very similar way to lower consumption taxes. On the supply side, they reduce the wedge between the real wage and the marginal rate of substitution in the same way, leading to higher labor supply but also a drop in pre-tax real wages. On the demand side, higher household incomes are now derived from a higher takehome pay for each hour of labor supplied, despite the drop in pre-tax real wages. This again results in an increase in private consumption, driven primarily by higher consumption of LIQ households. The increase in aggregate demand only partly offsets the downward pressure on pre-tax real wages from increased labor supply, so that inflation drops slightly. The resulting small drop in real interest rates implies a stronger performance of investment than for the case of lower consumption taxes. But the performance of consumption is considerably weaker, due to the absence of a drop in the after-tax price of consumption goods.

Lower capital income tax rates (Figure 8) raise the after-tax return to capital, which induces firms to invest more during the two years of the stimulus. Private consumption also increases slightly, due to the positive income and wealth effects that follow higher capital investment. Stronger private demand results in slightly higher inflation, and increases in nominal and real interest rates that, together with countercyclical fiscal policy, partly offset the effects of the stimulus.

Fiscal multipliers are well below unity for tax-based fiscal stimulus measures. The main reasons are the lack of a direct demand effect, and the very low marginal propensity of OLG households to consume the additional income.

In all three cases, the demand boost that follows the tax cuts leads to higher bank profits, increased share of banks' net worth on assets, and consequently lower wholesale lending spreads. The effects are smallest for a cut in labor income taxes, since the bank loans are procyclical and bank's net worth over loans improves only marginally. The effects are largest for a cut in capital income taxes. However, even for this case the differences between GIMFBGG and GIMF-BANKS in the behavior of investment and of GDP are small.

\section{Properties of Demand Shocks}

This section presents the effects of temporary shocks to private domestic demand in the United States. We will study two shocks, a shock to the policy interest rate, which is typically grouped with demand shocks because its primary effect is on aggregate demand, and a combined shock to private domestic consumption and investment. 


\section{A. Temporary Increase in the Policy Rate}

Figure 9 shows the effects of a shock that increases the U.S. nominal policy interest rate by 100 basis points on impact, with real interest rates increasing by a similar amount due to sticky nominal goods price inflation. As a result, U.S. GDP decreases by almost 0.7 percent on impact, and headline inflation decreases by over 0.2 percentage points at its trough in the second year. Higher real interest rates reduce private investment due to a higher user cost of capital. This leads to a drop in income and wealth, which together with intertemporal substitution contributes to a drop in consumption. Higher real interest rates also appreciate the real effective exchange rate, but this effect is temporary, as the real exchange rate returns to the baseline. Following the exogenously induced tightening, the monetary authority reduces the nominal interest rate in order to drive real interest rates below their neutral level, thereby temporarily stimulating aggregate demand and re-anchoring inflation at the target.

In GIMF-BANKS, monetary tightening leads to a drop in inflation that contributes to bank loan losses. Because these losses reduce bank capital adequacy ratios, the wholesale lending spread rises by around 8 basis points on impact, and then gradually returns to its original level. This however is almost completely offset by a smaller increase in the external financing spread relative to GIMF-BGG. The differences in the behavior of investment and GDP are therefore close to zero.

\section{B. Temporary Increase in Private Domestic Demand}

Figure 10 shows the effects of a one-year one percentage point increase in U.S. private consumption accompanied by a one-year four percentage point increase in U.S. private investment. While the shock itself has no persistence, its effects nevertheless unwind only gradually because there is internal propagation in consumption (due to habit persistence) and investment (due to investment adjustment costs). Under this shock, GDP increases by just over 1 percent in the short run. Higher investment accumulates over time into a higher private capital stock, and this causes a small but longer-lasting increase in output. Inflation peaks at around $0.25-0.30$ percentage points above its target during the second year following the shock. The resulting countercyclical increase in the policy interest rate drives up real interest rates and appreciates the real effective exchange rate. Fiscal policy also reacts countercyclically to the pickup in real activity.

The transmission mechanism of the shock in Figure 10 is very similar to the fiscal stimulus shocks in Section III, because both types of shocks are to (different) components of aggregate demand, and both are similar in magnitude. Therefore, the differences between GIMF-BGG and GIMF-BANKS also follow a similar pattern, with a small improvement in bank profits and capital-adequacy ratios and a small reduction in the wholesale lending premium. The differences in the behavior of both investment and GDP are again small. 


\section{Properties of Supply Shocks}

This section studies the effects of supply shocks, including a one-off permanent increase in the level, and a persistent increase in the growth rate, of labor-augmenting productivity, one-off permanent reductions in wage markups and price markups, and one-off permanent increases in tariffs.

\section{A. Productivity Shocks}

\section{Permanent Increase in the Level of Productivity}

Figure 11 shows the effects of a permanent one percent increase in the level of labor augmenting productivity in both the tradable and nontradable intermediate goods sectors in the United States. Higher productivity increases the marginal product of capital, which boosts investment, as well as increasing household income and wealth, which boosts private consumption. Because the increase in productivity is large and immediate, its disinflationary effect initially dominates despite the inflationary effects of higher aggregate demand, but the effect is not large at around 0.05 percentage points during the first and second years following the shock. Nevertheless, the resulting decline in the policy rate, by driving down real interest rates, exerts additional upward pressure on investment and consumption. The real effective exchange rate persistently depreciates, reflecting the drop in domestic costs of production. The trade balance goes into a prolonged deficit, due to a boom in investment as the capital stock permanently adjusts to a higher level commensurate with the higher level of productivity.

For this shock, there is little difference between GIMF-BGG and GIMF-BANKS, again. The reason is that the spread between retail and deposit rates in both models is very small, given the size of the shock. The positive supply shock makes entrepreneurs less risky and more in need of expanding their borrowing to finance the increase investment activity. In GIMF-BGG the rate of corporate insolvencies drops more than in GIMF-BANKS, which is consistent with average lower external financing spread. Banks are willing to extend the loans to entrepreneurs and by as a result their loan book expands faster than their net worth, resulting in a small increase in wholesale lending spread.

\section{Persistent Increase in the Growth Rate of Productivity}

Figure 12 shows the effects of a ten-year anticipated increase in the growth rate of economywide labor-augmenting productivity in the United States. The size of the increase in productivity is calibrated to increase the steady-state level of real GDP each year by just under 0.25 
percent, which results in an increase in the level of real GDP by the end of ten years of just over 2 percent.

Because the increase in productivity is anticipated, it results in an immediate increase in income and wealth, and therefore in a sizeable increase in private domestic demand that in large part, due to consumption smoothing on the part of OLG households, precedes the actual realizations of the productivity gains. There are two competing effects on inflation. First, the successive increases in productivity put downward pressure on marginal cost and thus on prices, but this effect is gradual. Second, the increase in aggregate demand puts immediate upward pressure on prices. This second effect dominates during the transition, with headline inflation increasing, albeit modestly, by just over 0.15 percentage points at the peak in years $3-5$. Countercyclical monetary policy increases real interest rates by around 20 basis points at the peak and appreciates the real exchange rate on impact, accompanied by a trade balance deficit during a lengthy transition. In the long run, however, the real effective exchange rate depreciates in order to permanently increase external demand for the increased U.S. output.

The differences between GIMF-BGG and GIMF-BANKS are again small. Anticipated productivity growth shocks share many characteristics with demand shocks, as evidenced by the behavior of inflation. We therefore observe, as we have previously observed for demand shocks, that banks make lending profits, improve their capital-adequacy ratio, and lower the wholesale lending spread. But the effect on the latter is very small, at 2 basis points on impact, and the movement in the external financing spread partly offsets this. As a result, the behavior of GDP is indistinguishable between the two models.

\section{B. Permanent Drop in Wage Markups}

Figure 13 shows the effects of a permanent increase in the degree of U.S. labor market competition that reduces the wage markup by five percentage points. Firms respond to lower wage markups by increasing hiring and investment. The permanent increase in production generates an increase in aggregate income and wealth, which leads to higher consumption. In the long run, real GDP increases by almost 1.5 percent, accompanied by mild disinflationary pressures and by a mild drop in policy and real interest rates that stimulates additional output gains, directly and through a depreciation of the real exchange rate. Similar to the case of productivity shocks, the real exchange rate remains depreciated in the long run, in order to permanently increase external demand for the increased U.S. output. Similar to the results for productivity shocks, the differences between GIMF-BGG and GIMF-BANKS for wage markup shocks are small. 


\section{Permanent Drop in Price Markups}

Figure 14 shows the effects of a permanent increase in the degree of U.S. goods market competition that reduces the price markup over marginal cost in the tradable and nontradable goods sectors by five percentage points. Firms respond to greater goods market competition by increasing hiring and investment. The permanent increase in production generates an increase in aggregate income and wealth, which implies higher consumption. The expansion in the economy's supply capacity raises real GDP by more than 5 percent in the long run. Despite the downward pressure on price inflation from reduced price markups, along the adjustment path to the new equilibrium overall CPI inflation rises by almost 0.4 percentage points. This is because demand effects are initially very strong, most importantly due to an investment surge that brings the capital stock to a permanently higher level that is consistent with reduced monopolistic distortions in the goods market. In response to the increase in inflation, policy and real interest rates rise to return inflation to target. Similar to the case of productivity shocks, the real exchange rate depreciates in the long run, in order to permanently increase external demand for the increased U.S. output. The differences between GIMF-BGG and GIMF-BANKS are again small. The effects of this shock on the financial sector are expansionary due to the behavior of inflation.

\section{Permanent Increase in Tariffs}

Figure 15 shows the effects of a permanent, ten percentage point increase in U.S. tariffs on imports from all other regions. Because this increases supply-side distortions in the economy, GDP permanently decreases by around 1 percent, with most of the drop taking place over the first two years, while private investment declines by 2 percent in the short run, and by around 1.5 percent in the long run. Consumption increases strongly as additional income from tariffs is distributed to households via permanently higher general transfers, which increases LIQ consumption due to higher incomes and OLG consumption due to higher wealth. The long-run increase in consumption is around 0.7 percent. Headline inflation increases only marginally in the short run, as a large nominal appreciation offsets the increase in import prices due to higher tariffs. Because tariffs raise the relative price of imports, import volumes decline. This is accompanied by a real appreciation that reduces foreign demand for U.S. exports, thereby keeping the trade balance approximately in balance, and maintaining the desired level of net foreign assets.

The differences between GIMF-BGG and GIMF-BANKS are once more small. On impact banks make small losses. Thereafter, the effects of the shock on real activity and thus on lending are permanent, while banks manage to replace lost equity fairly quickly. As a result, beyond the first two years bank capital-adequacy ratios are improved, and wholesale lending spreads reduced. 


\section{Properties of Financial Sector Shocks}

This section presents the effects of a number of shocks to the U.S. financial sector. First, as in Anderson and others (2013), we simulate a temporary increase in borrower riskiness, under two alternative assumptions, an equal impact effect on the external financing spread and an equal shock size. Because shocks to borrower riskiness are present in both GIMF-BGG and GIMF-BANKS, these simulations can be performed as a comparison across the two models, as in all other figures up to this point. Second, we simulate the effects of different settings for macroprudential policy, specifically for minimum capital-adequacy ratios (MCAR). Because these are only present in GIMF-BANKS, the simulations compare different versions of that model. One simulation subjects the economy to a shock to borrower riskiness, under the alternative assumptions of fixed or countercyclical MCAR. Another simulation studies the effects of a permanent increase in MCAR, under the alternative assumptions of immediate or gradual implementation.

\section{A. Temporary Increase in Borrower Riskiness}

\section{Equal Impact Effect on External Financing Spread}

Figure 16 shows the effects of a temporary but persistent increase in the riskiness of U.S. corporate borrowers. In this simulation the shock sizes in GIMF-BGG and GIMF-BANKS are chosen such that on impact external financing spreads increase by 1 percentage point in both models.

In both versions of GIMF, the main effect of higher external financing spreads is to reduce investment and the capital stock. The resulting loss in household income and wealth also depresses consumption, despite a reduction in the real risk-free interest rate as the monetary authority responds to lower inflation. The trade balance improves modestly, and real GDP declines.

There are more notable differences between GIMF-BGG and GIMF-BANKS in this simulation. In GIMF-BANKS, the sizeable increase in borrower riskiness leads to much higher loan defaults than originally anticipated by banks, and thus to sizeable lending losses that reduce the average capital adequacy ratio by a full two percentage points, that is from 10.5 percent in the baseline to 8.5 percent following the shock. Because actual capital-adequacy ratios of individual banks are heterogeneous across institutions, this implies that many banks now either violate the MCAR of 8 percent, or are very close to doing so. They therefore rush to rebuild their equity buffers, by raising the wholesale lending spread by over 70 basis points on impact and thereby quickly increasing their profits. Given that the external financing spread has been normalized here to increase by 100 basis points on impact in both models, the real 
lending rate in GIMF-BANKS therefore increases by an additional 70 basis points. The behavior of bank loans is consequently also very different, with a smooth and modest decrease in loans in GIMF-BGG, but a drop in loans of almost 3 percent on impact in GIMF-BANKS. Given the greater increase in real lending rates and the larger decline in the volume of lending in GIMF-BANKS, the effects of this shock on the real economy are also larger, with GDP, consumption and investment all contracting by roughly twice as much as in GIMF-BGG.

Figure 17 turns to the question of why the increase in borrower riskiness leads to belowaverage returns to lending at the previously set lending rate, and thus to losses and a precipitous decline in capital-adequacy ratios. To study this we need to again examine equation (1). First, the real ex-post cost of bank wholesale borrowing $r_{\ell, t} \check{\ell}_{t-1}$ increases, because following the shock inflation is lower than expected at the time of contracting the loan. However, given the very small change in inflation, this effect is negligible in size. Second, and more importantly, banks' income from lending $q_{t-1} \breve{k}_{t-1} r e t_{k, t} \gamma_{t}$ decreases, which accounts for close to 100 percent of loan losses. The reason is that the increase in borrower riskiness leads to a significantly lower financial return to capital $\operatorname{ret}_{k, t} q_{t-1} \check{k}_{t-1}$, and unlike for all other shocks studied so far, banks' share in that return $\gamma_{t}$ does not increase in an offsetting fashion, but rather remains approximately constant. To understand this, we need to consider the formula for the ex-post cutoff productivity level $\bar{\omega}_{t}$ below which borrowers default. This is given by

$$
\bar{\omega}_{t}=\frac{r_{r, t} \check{\ell}_{t-1}}{q_{t-1} \check{k}_{t-1} r e t_{k, t}},
$$

where $r_{r, t}$ is the real retail lending rate. The denominator of this expression, except for $r e t_{k, t}$, is predetermined. This means that the cutoff productivity level $\bar{\omega}_{t}$ moves inversely with the financial return to capital $r e t_{k, t} q_{t-1} \breve{k}_{t-1}$. Furthermore, it can be shown that, for a given distribution over borrower productivity levels, banks' share $\gamma_{t}$ in the financial return to capital increases approximately one-for-one with the cutoff productivity level $\bar{\omega}_{t}$, and therefore also moves inversely with the financial return to capital $\operatorname{ret}_{k, t} q_{t-1} \breve{k}_{t-1}$. This implies that the product $q_{t-1} \breve{k}_{t-1} r e t_{k, t} \gamma_{t}$ would ordinarily remain close to constant when the financial return to capital changes, thereby keeping loan losses from this source small. This is in fact what we have observed for all other shocks. However, this no longer holds when the distribution over borrower productivity levels itself changes, and that is of course the very definition of borrower riskiness shocks. Specifically, when borrower riskiness increases, banks experience higher defaults at the same cutoff productivity level $\bar{\omega}_{t}$, thereby reducing banks' share $\gamma_{t}$ in the financial return to capital. In our simulation this downward pressure on $\gamma_{t}$ approximately offsets the upward pressure due to a lower financial return to capital, leaving $\gamma_{t}$ approximately unchanged and thereby accounting for large loan losses. 


\section{Equal Size of Shock to Borrower Riskiness}

Figure 18 again simulates shocks to borrower riskiness, but in this case the size of the shocks, rather than the size of the increase in the external financing spread, is assumed to be equal across models. The size of the shocks is chosen to equal the shock in GIMF-BGG in Figure 16. The impulse responses for GIMF-BGG in Figure 18 are therefore identical to those in Figure 16. With this normalization we observe significantly smaller differences in the real effects of the shocks.

The reason is the behavior of spreads. In GIMF-BANKS, the wholesale lending spread rises by almost 50 basis points on impact, and ceteris paribus this significantly reduces the leverage of corporate borrowers. We have already seen this in the behavior of bank loans in Figure 16, and encounter it again in Figure 18. Because bank loans drop by far more in GIMF-BANKS, the external financing spread is significantly lower, which offsets the effect of the higher wholesale lending spread on overall lending rates. The offset is not complete, so that differences remain between overall lending rates. But the differences in the behavior of investment, consumption and GDP are now far smaller than in Figure 16. Essentially, in Figure 16, to compensate for the offset evident in Figure 18, shocks to borrower riskiness under GIMFBANKS had to be much larger to generate an identical external financing spread. It is this difference in shock sizes that accounted for the major part of the large differences between GIMF-BANKS and GIMF-BGG.

\section{B. Shocks to Macroprudential Policy Settings in GIMF-BANKS}

\section{Fixed versus Countercyclical MCAR}

In Figure 19 we simulate a shock to the external financing spread in GIMF-BANKS, with the size of the shock equal to 100 basis points on impact, as in Figure 16. The assumption underlying the blue solid line, labelled "Fixed MCAR", is that the MCAR is held constant at 8 percent of total assets. This simulation is therefore identical to the solid line in Figure 16. The assumption underlying the red dashed line, labelled "Countercyclical MCAR", is that the MCAR is equal to that same constant plus a feedback term that is increasing in the percentage deviation of loans from their initial value.

In both simulations banks' actual capital-adequacy ratio drops by around two percentage points on impact, due to the loan losses that follow contractionary shocks to borrower riskiness. With fixed MCAR, this puts a lot of banks below or near the point where they have to start paying penalties. This triggers a steep increase in the wholesale lending spread of around 70 basis points, as banks start to rebuild lost equity. Taken together with the increase in the external financing spread, which reflects the elevated riskiness of borrowers, this causes a steep initial contraction of investment, and therefore also of GDP. 
On the other hand, with countercyclical MCAR, the regulator responds to a reduced lending volume by temporarily lowering the MCAR, so that banks can rebuild their lost equity over time instead of having to do so immediately. As a result the wholesale lending spread increases far less dramatically, while the increase in the external financing spread is approximately the same as under fixed MCAR. Overall lending rates therefore increase by far less, and as a result the impact effect of the shock is only about half as large as under the fixed MCAR assumption, and thereafter smoothed over time.

GIMF-BANKS therefore contains additional lessons for policy that could not be obtained using GIMF-BGG, because in the latter bank equity, and a meaningful role of bank balance sheets, is absent. It should be noted, that the model does not consider the possibility that the regulation may push activity and associated risks into the shadow banking system, as in Kashyap, Berner, and Goodhart (2011), for instance.

\section{Immediate versus Gradual Increase in MCAR}

Figure 20 simulates an increase in the fixed component, rather than in the countercyclical component, of capital-adequacy regulations. Specifically, this figure assumes that the MCAR itself is permanently raised from its original value of 8 percent of total assets to a new steady state value of 10 percent of total assets. The blue solid line assumes that this increase becomes mandatory immediately, while the red dashed line assumes that the MCAR is gradually, and linearly, increased over a period of five years.

Under the immediate increase of the MCAR, banks that were previously solidly capitalized suddenly find that they are close to or below the new MCAR. They therefore rush to quickly build up additional equity, by raising the wholesale lending spread rapidly by almost 90 basis points on impact. This higher spread, despite a simultaneous drop in the volume of lending, makes borrowers less creditworthy, and therefore also increases the external financing spread, by just over 10 basis points. This adds up to a roughly 100 basis points increase in lending spreads, which is only very partially buffered by a 20 basis points reduction in the policy rate. As a result, there is a small but significant contraction of GDP by around 0.3 percent on impact, while the long-run contraction of GDP equals only around 0.1 percent. The faster attainment of a higher capital ratio therefore comes at the cost of slightly more volatile output.

Under the gradual increase in MCAR this is smoothed. Now banks have more time to build up additional equity, and as a result the wholesale lending spread increases more modestly, and without spiking on impact. The external financing spread barely increases on impact and then quickly declines. The much smoother behavior of real lending rates is reflected in a much smoother behavior of the real economy. 
We also observe interesting long-run effects of higher MCAR. The wholesale lending spread increases by 8 basis points, as banks are permanently obliged to accumulate additional earnings in order to maintain a higher capital buffer. This however has the side effect of reducing the long-run volume of bank loans by around 0.5 percent. Because this implies permanently lower borrower leverage, the external financing spread is permanently lower by 2 basis points, which partly offsets the increase in the wholesale lending spread. The final effect on real GDP is modest, there is an approximately 0.1 percent contraction.

\section{Conclusion}

This paper has studied the comparative simulation properties of the two versions of the GIMF model. The first is GIMF with a conventional financial accelerator, referred to as GIMF-BGG, which has been used at the IMF for policy and scenario analysis since 2008, and whose simulation properties have been extensively studied in Anderson and others (2013). In this model banks play an important role in pricing risky loans, but their balance sheets do not play an important role, principally because banks write state-contingent lending contracts whereby they make zero profits in all states of nature, and therefore do not require equity to protect their depositors against adverse shocks. State-contingent lending contracts do serve to greatly simplify financial accelerator models. But their drawback is a lack of realism, as in real-world lending banks' payoff is invariant to the state of nature except when borrowers default. In that world bank balance sheets are of critical importance, and this importance has been widely acknowledged following the financial crisis that triggered the Great Recession. The second version of GIMF, referred to as GIMF-BANKS, therefore adopts a different specification of the banking sector, while remaining identical to GIMF-BGG in all other respects. In this model banks cannot write fully state-contingent lending contracts, and as a result generally make profits or losses when the economy experiences macroeconomic shocks. Because banks also face regulatory constraints that represent Basel-III capital-adequacy regulations, bank equity assumes a critical role as a shock absorber, and bank balance sheets become an essential part of the model.

The simulation results presented in this paper have taken the form of contrasting the properties of GIMF-BGG and GIMF-BANKS, and also to explore some new properties of macroprudential regulation that are only present in GIMF-BANKS. The main results are as follows. First, following standard fiscal, demand and supply shocks, the properties of GIMF-BGG and GIMF-BANKS are very similar. The reason is that, for a given distribution over borrower productivity levels, meaning in the absence of financial shocks, banks' net loan losses remain small. Second, following financial shocks, meaning when the distribution over borrower productivity levels itself changes, there are notable differences in the properties of GIMF-BGG and GIMF-BANKS. Taking as an example a contractionary shock to borrower riskiness, the reason is that in this case not only do borrowers experience a reduction in the return on their 
projects, in addition banks experience a reduction, ceteris paribus, in their share of the return on those projects. This causes loan losses and a deterioration in regulatory capital-adequacy ratios, in response to which banks will tend to increase lending spreads for all borrowers, including riskless ones. This mechanism is absent in GIMF-BGG, which therefore exhibits substantially smaller effects of contractionary financial shocks. Third, GIMF-BANKS can also be used to study an additional set of shocks to macroprudential policy instruments that are absent in GIMF-BGG. This can potentially generate valuable insights for policy. 


\section{REFERENCES}

Anderson, D., Hunt, B., Kortelainen, M., Kumhof, M., Laxton, D., Muir, D., Mursula, S. and Snudden, S. (2013), "Getting to Know GIMF: The Simulation Properties of the Global Integrated Monetary and Fiscal Model”, IMF Working Paper Series, WP/13/55, available at http://www.imf.org/external/pubs/cat/longres.aspx?sk=40357.0.

Angeloni, I. and Faia, E. (2009), "A Tale of Two Policies: Prudential Regulation and Monetary Policy with Fragile Banks", IMF The Kiel Institute for the World Economy Working Paper Series, No. 1569

Benes, J. and Kumhof, M. (2011), "Risky Bank Lending and Optimal Capital Adequacy Regulation", IMF Working Paper Series, WP/11/130, available at http://www.imf.org/external/pubs/cat/longres.aspx?sk=24900.0.

Bernanke, B.S., Gertler, M. and Gilchrist, S. (1999), “The Financial Accelerator in a Quantitative Business Cycle Framework”, in: John B. Taylor and Michael Woodford, eds., Handbook of Macroeconomics, Volume 1C. Amsterdam: Elsevier.

Blanchard, O.J. (1985), "Debt, Deficits, and Finite Horizons", Journal of Political Economy, 93, 223-247.

Christiano, L., Motto, R. and Rostagno, M. (2010), "Financial Factors in Economic Fluctuations", ECB Working Paper Series, No. 1192.

Christiano, L., Motto, R. and Rostagno, M. (2014), "Risk Shocks", American Economic Review, 104(1), 27-65.

Coenen, G., C. Erceg, C. Freedman, D. Furceri, M. Kumhof, R. Lalonde, D. Laxton, J. Lindé, A. Mourougane, D. Muir, S. Mursula, J. Roberts, W. Roeger, C. de Resende, S. Snudden, M. Trabandt, J. in't Veld (2012), "Effects of Fiscal Stimulus in Structural Models", American Economic Journal: Macroeconomics, 4(1), 22-68.

Curdia, V. and Woodford, M. (2010), "Credit Spreads and Monetary Policy, Journal of Money, Credit, and Banking, 24(6), 3-35.

Fecht, F., Grüner, H.P. and Hartmann, P. (2012), "Financial Integration, specialization, and systemic risk”, Journal of International Economics, 88, 150-161.

Gerali, A., Neri, S., Sessa, L. and Signoretti, E. (2010), “A Tale of Credit and Banking in a DSGE Model of the Euro Area", Bank of Italy Working Paper Series, No. 740 
Gertler, M. and Karadi, P. (2011), “A Model of Unconventional Monetary Policy, Journal of Monetary Economics, 58, 17-34.

Goodhart, Ch.A.E., Kashyap, A.K., Tsomocos, D.P. and A.P. Vardoulakis (2012), "Financial Regulation in General Equilibrium”, NBER Working Paper Series, WP 17909, available at http://www.nber.org/papers/w17909.pdf.

Guerrieri, L. and Iacoviello, M. (2013), "Collateral Constraints and Macroeconomic Asymmetries", International Finance Discussion Papers No.1082, Board of Governors of the Federal Reserve System

Kashyap, A.K., Berner, R. and Ch.A.E. Goodhart (2011), “The Macroprudential Toolkit”, IMF Economic Review, 59(2), 145-161.

Kollmann, R. (2013), “Global Banks, Financial Shocks, and International Business Cycles: Evidence from an Estimated Model, Journal of Money, Credit, and Banking, 45(2), 159-195.

Kumhof, M. and D. Laxton (2007), "A Party Without a Hangover? On the Effects of U.S. Fiscal Deficits”, IMF Working Paper Series, WP/07/202, available at http://www.imf.org/external/pubs/ft/wp/2007/wp07202.pdf.

Kumhof, M. and D. Laxton (2013), "Fiscal Deficits and Current Account Deficits," Journal of Economic Dynamics and Control, 37(10), 2062-2082.

Kumhof, M., D. Laxton, D. Muir and S. Mursula (2010), “The Global Integrated Monetary Fiscal Model (GIMF) - Theoretical Structure", IMF Working Paper Series, WP/10/34, available at http://www.imf.org/external/pubs/cat/longres.cfm?sk=23615.0.

Milne, A. (2002), "Bank Capital Regulation as an Incentive Mechanism: Implications for Portfolio Choice", Journal of Banking and Finance, 26(1), 1-23 
Figure 1. Temporary Stimulus Through Government Consumption (1pc of GDP for 2 years)

Percent or percentage point deviation from steady-state baseline

(Horizontal axis is in years)

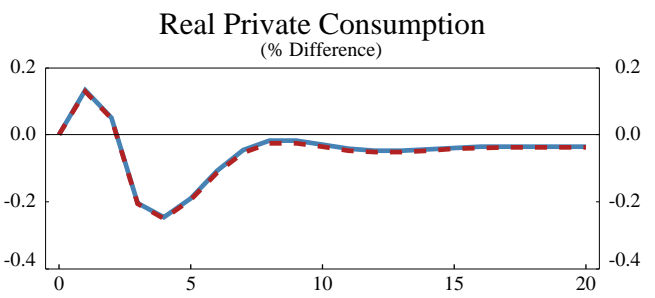

Real Private Investment
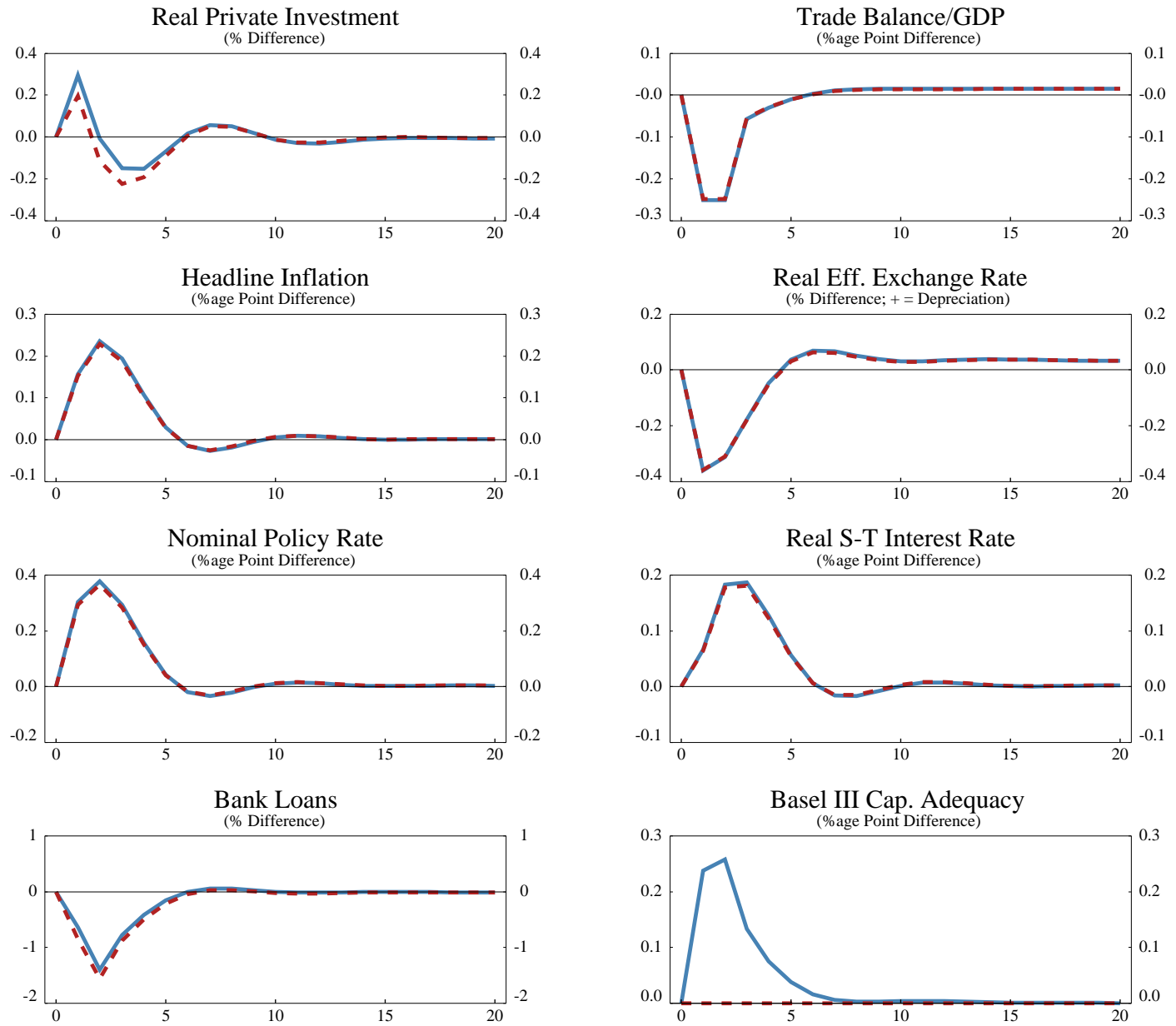

Basel III Cap. Adequacy

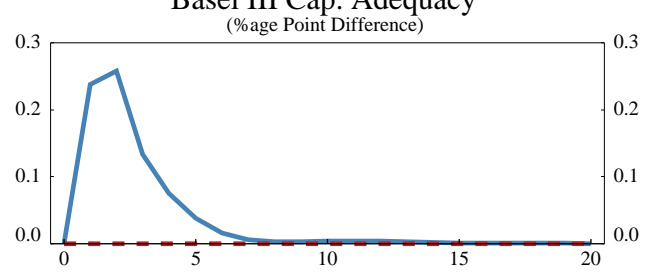

External Financing Spread

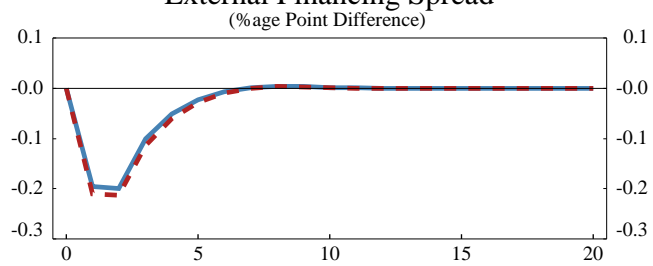

Regulatory Lending Spread

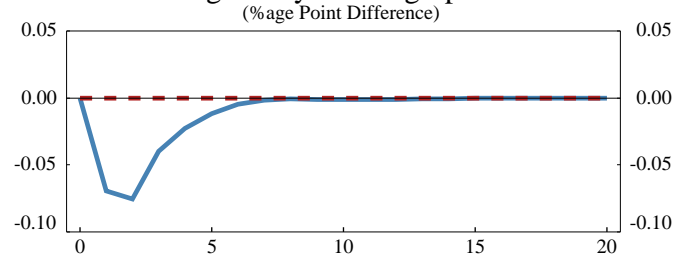


Figure 2. Temporary Stimulus Through Government Investment (1pc of GDP for 2 years)

Percent or percentage point deviation from steady-state baseline (Horizontal axis is in years)

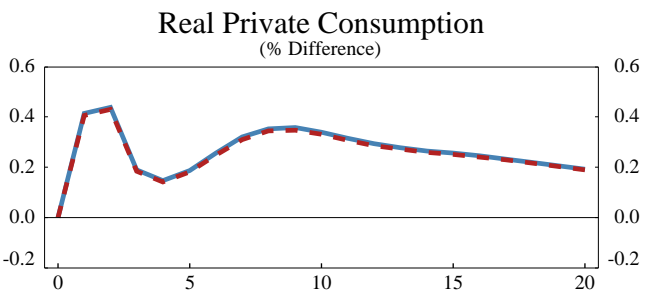

Real Private Investment (\% Difference)

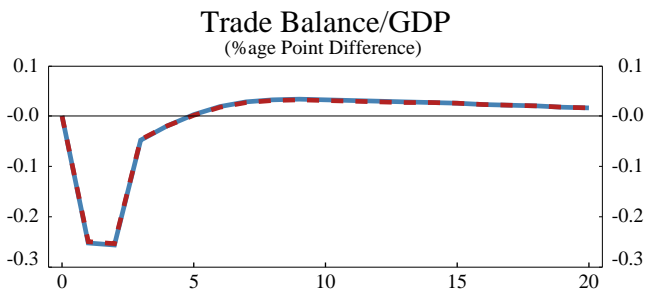

$\underset{\text { (\%age Point Difference) }}{\text { Headline Inflation }}$
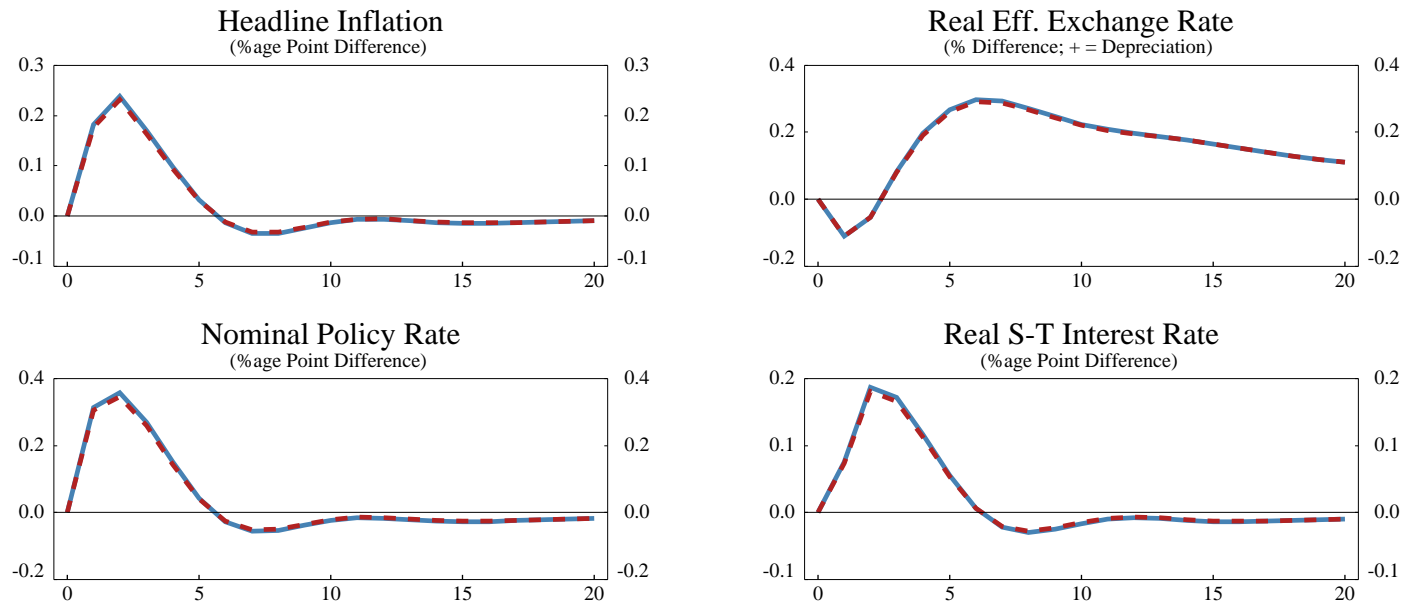

Real S-T Interest Rate
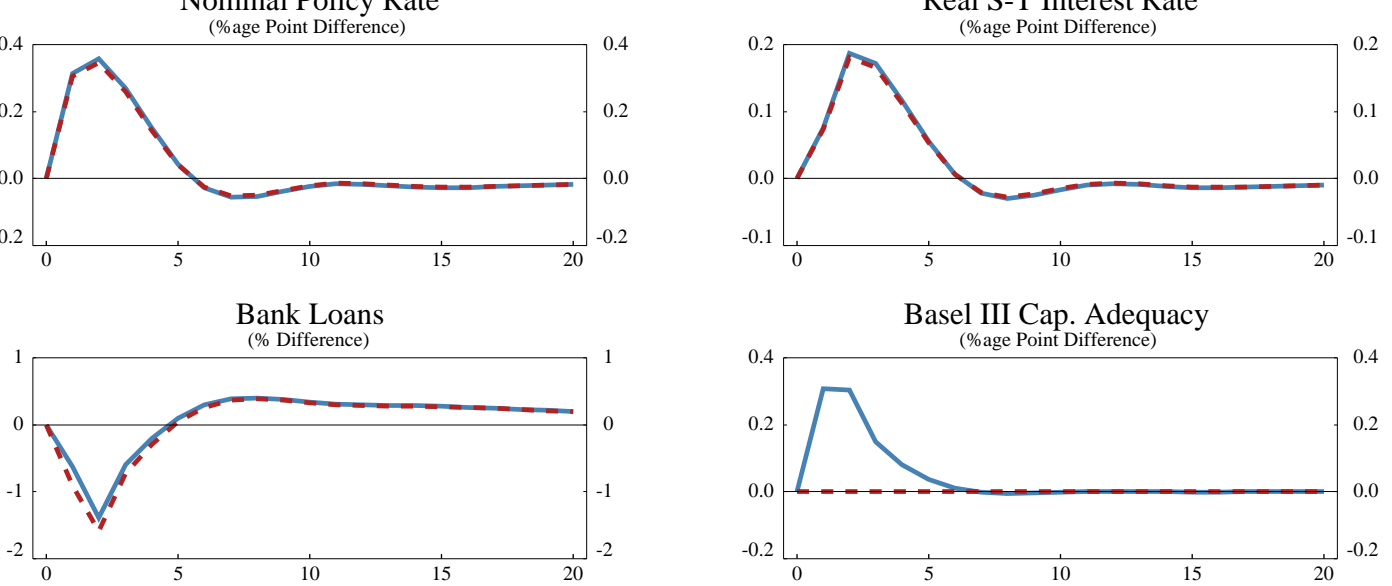

Basel III Cap. Adequacy

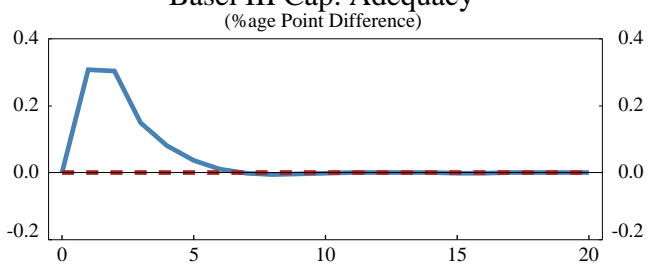

External Financing Spread

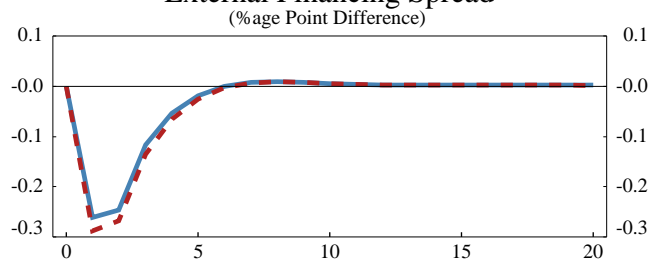

Regulatory Lending Spread

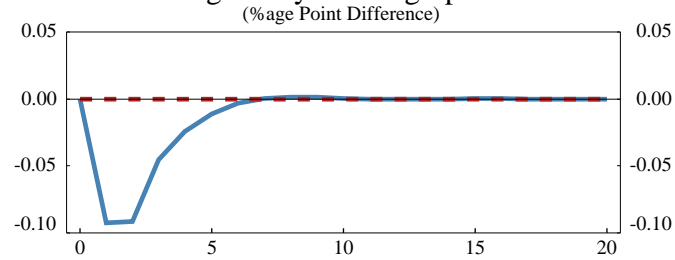


Figure 3. Temporary Stimulus Through Government Consumption - Bank Loan Losses
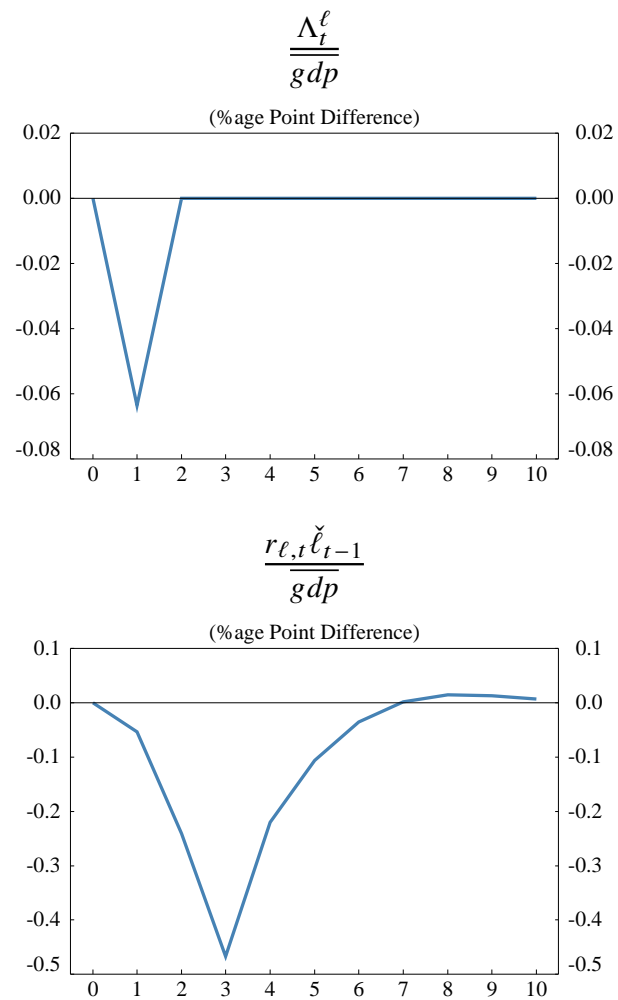

$$
\frac{q_{t-1} \breve{k}_{t-1} r e t_{k, t} \bar{\gamma}}{\overline{g d p}}
$$

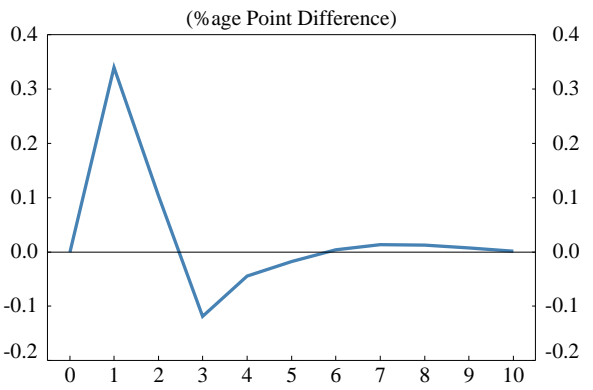

$\frac{\Lambda_{t}^{\ell}}{\bar{\ell}}$

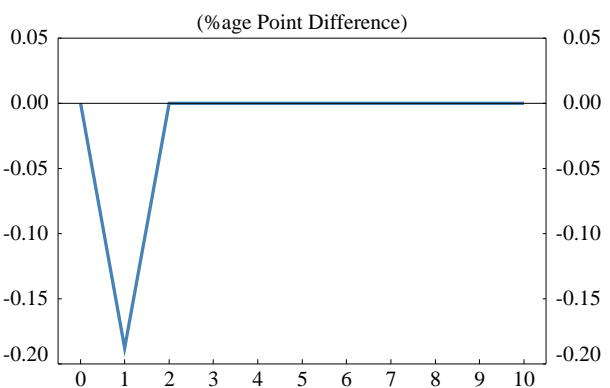

$\frac{q_{t-1} \check{k}_{t-1} r e t_{k, t} \gamma_{t}}{\overline{g d p}}$

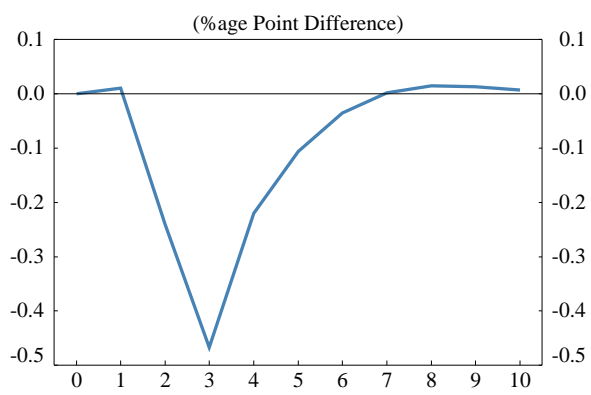

$\frac{q_{t-1} \breve{k}_{t-1} \overline{r e t_{k}} \gamma_{t}}{\overline{g d p}}$

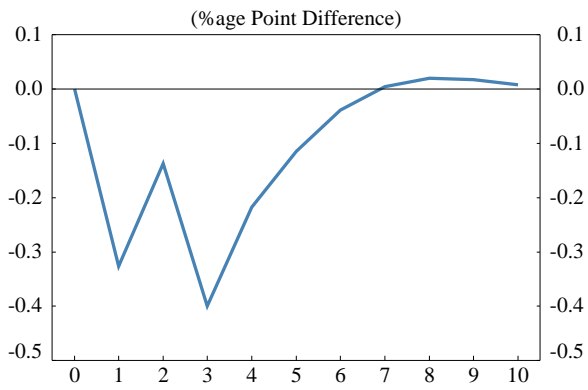


Figure 4. Temporary Stimulus Through Targeted Transfers (1pc of GDP for 2 years)

Percent or percentage point deviation from steady-state baseline
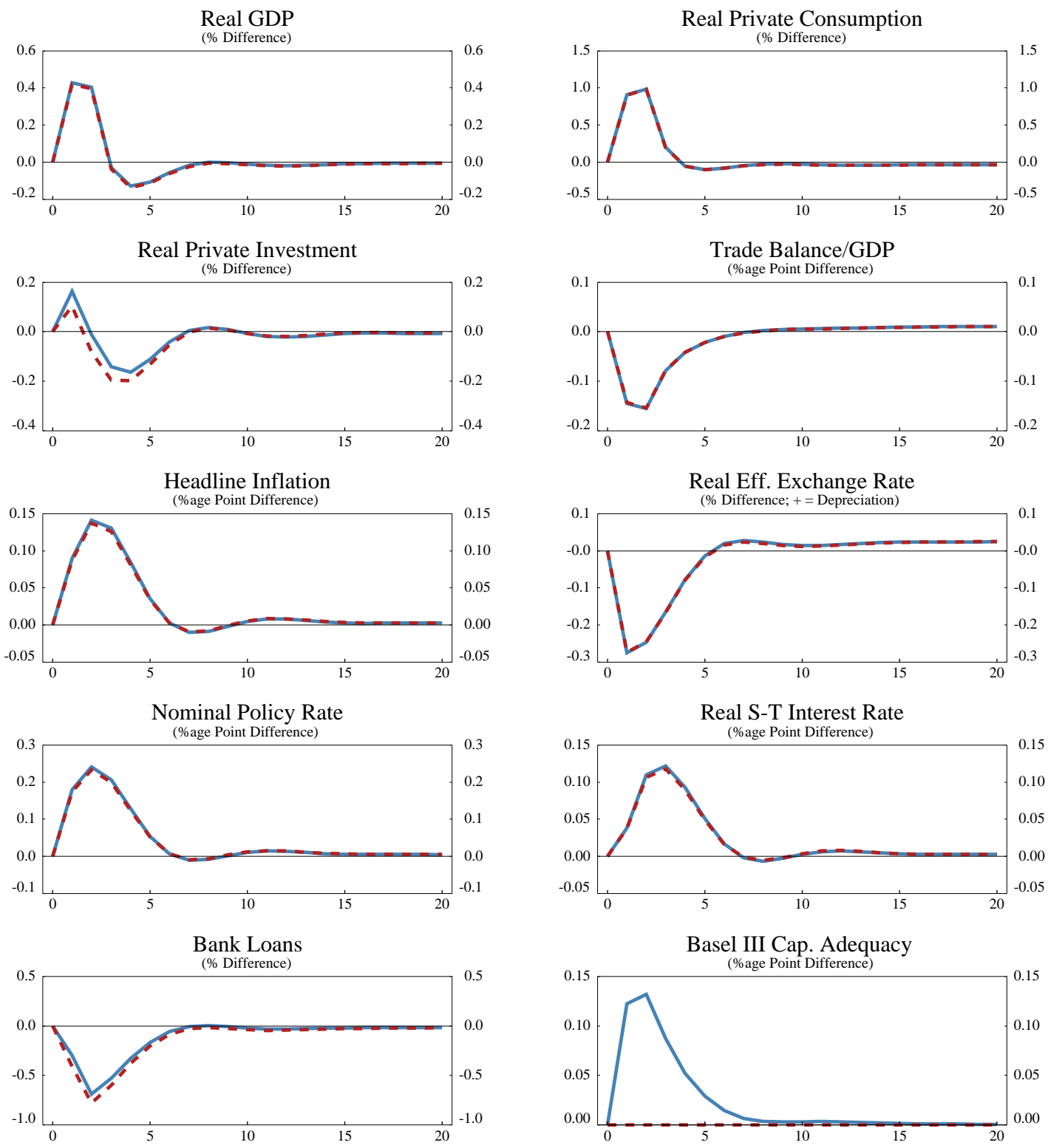

Basel III Cap. Adequacy

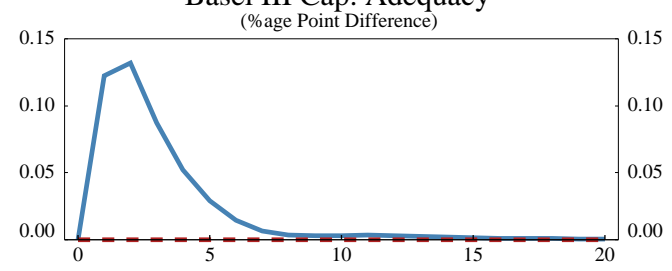

External Financing Spread

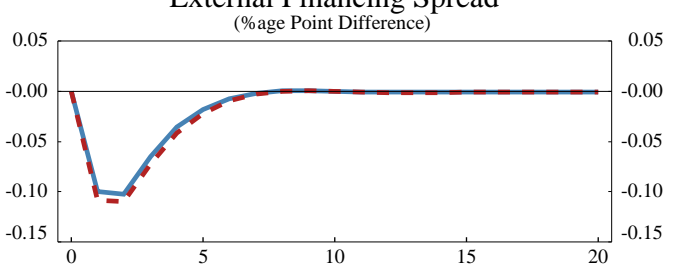

Regulatory Lending Spread

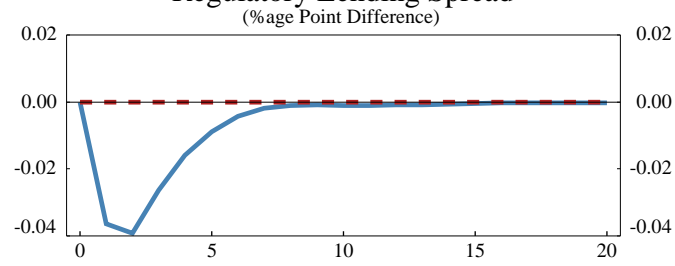


Figure 5. Temporary Stimulus Through General Transfers (1pc of GDP for 2 years)

Percent or percentage point deviation from steady-state baseline

(Horizontal axis is in years)

$-{ }_{--}$GIMF-BGG
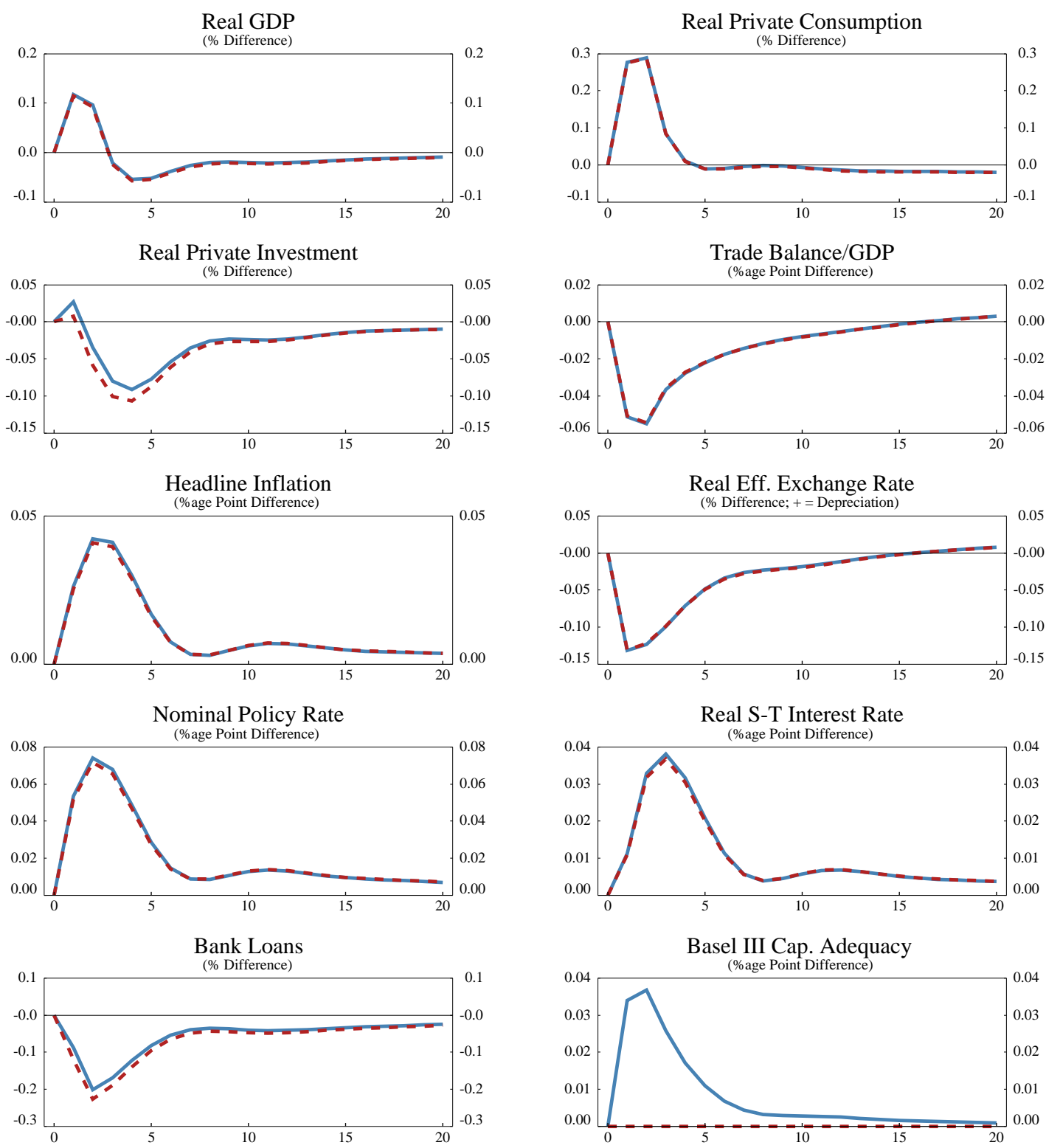

External Financing Spread

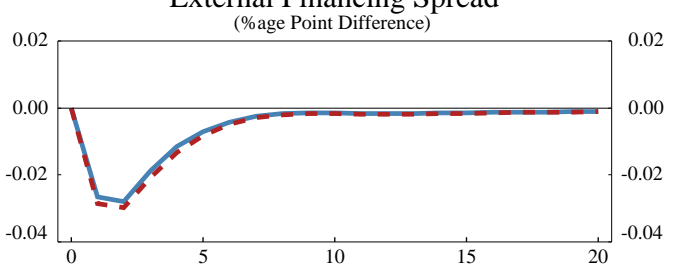

Regulatory Lending Spread

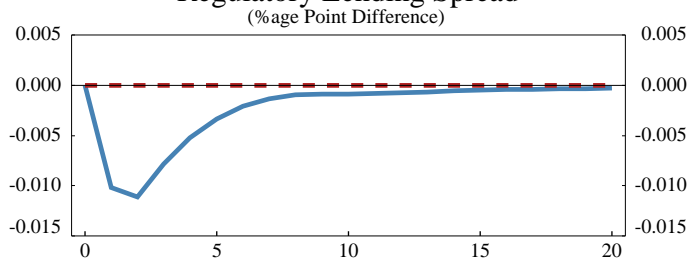


Figure 6. Temporary Stimulus Through Lower Consumption Taxes (1pc of GDP for 2 years)

Percent or percentage point deviation from steady-state baseline (Horizontal axis is in years)
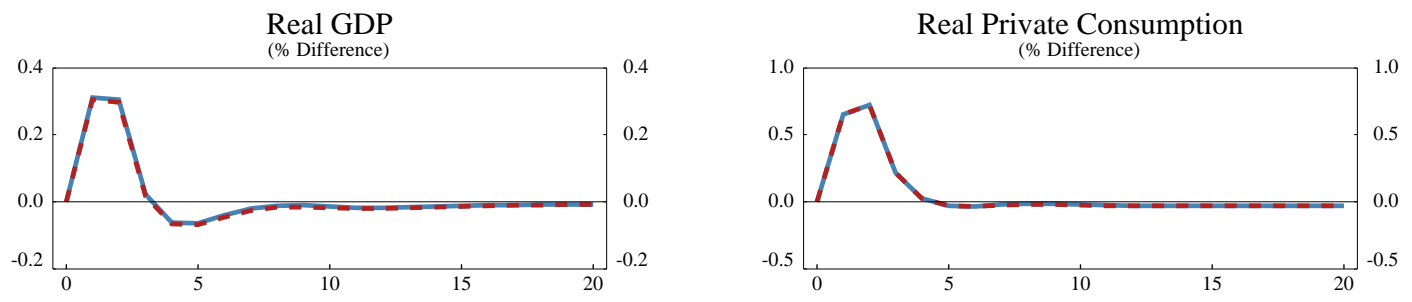

Real Private Investment
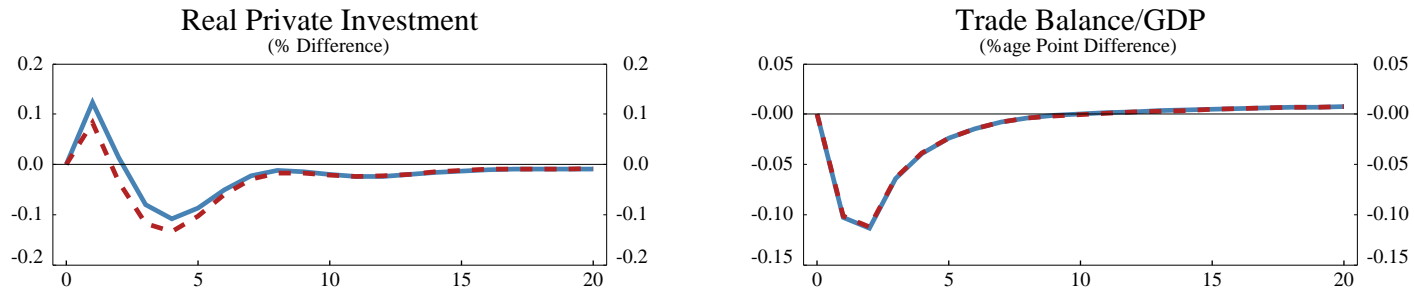

CPI Inflation excl. Indirect Taxes
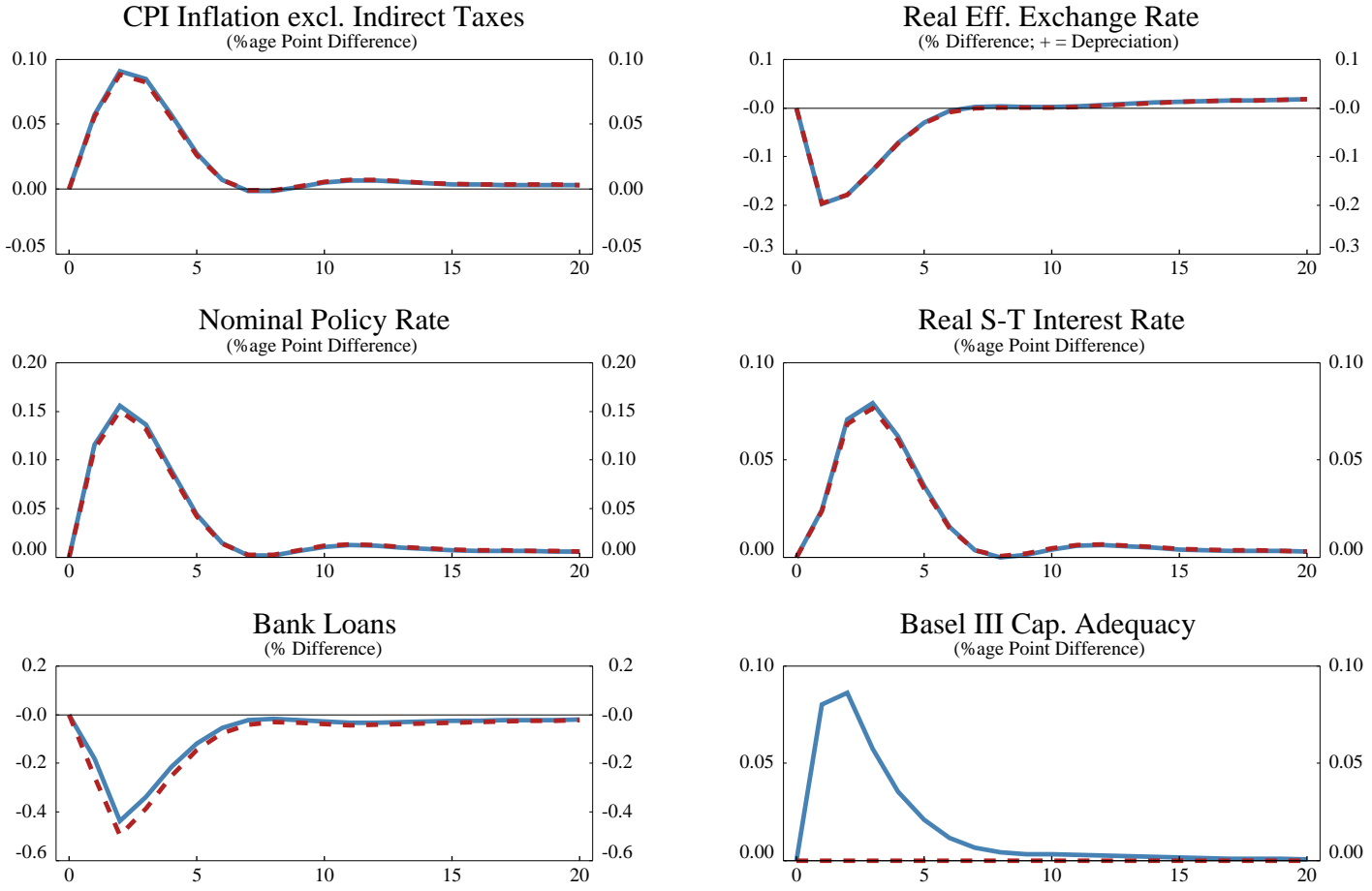

Basel III Cap. Adequacy

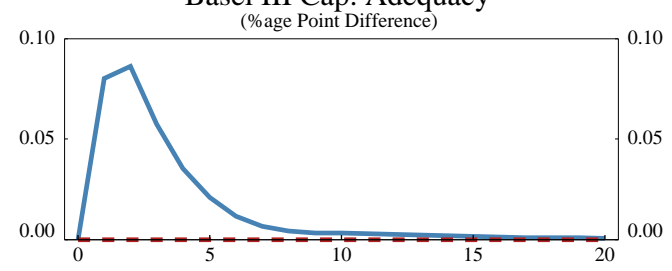

External Financing Spread

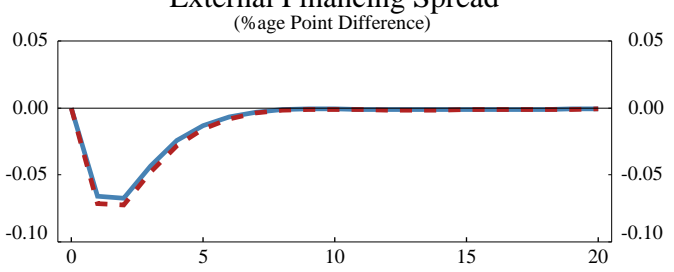

Regulatory Lending Spread

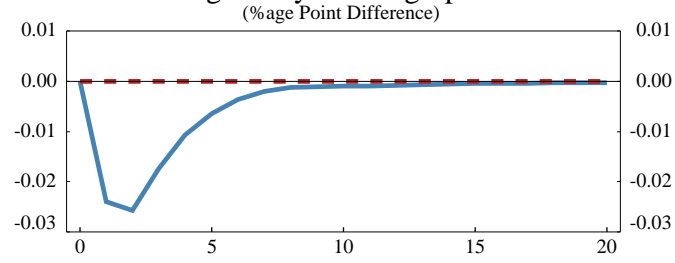


Figure 7. Temporary Stimulus Through Lower Labor Income Taxes (1pc of GDP for 2 years)

Percent or percentage point deviation from steady-state baseline (Horizontal axis is in years)
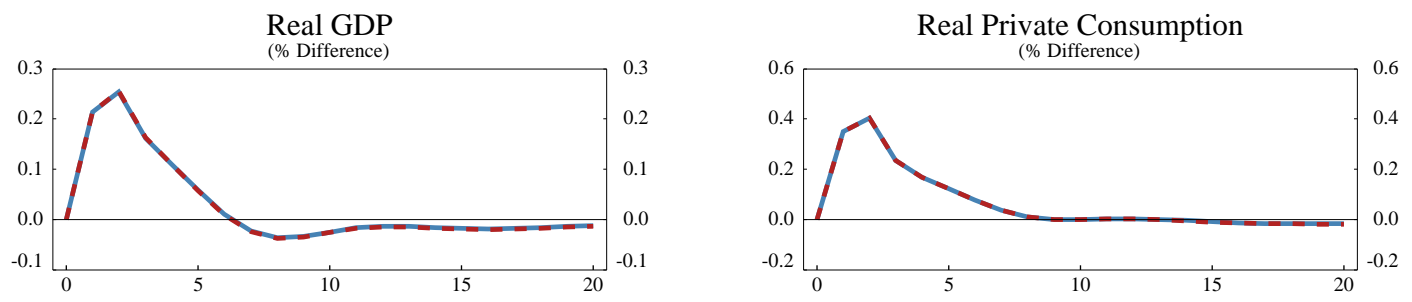

Real Private Investment
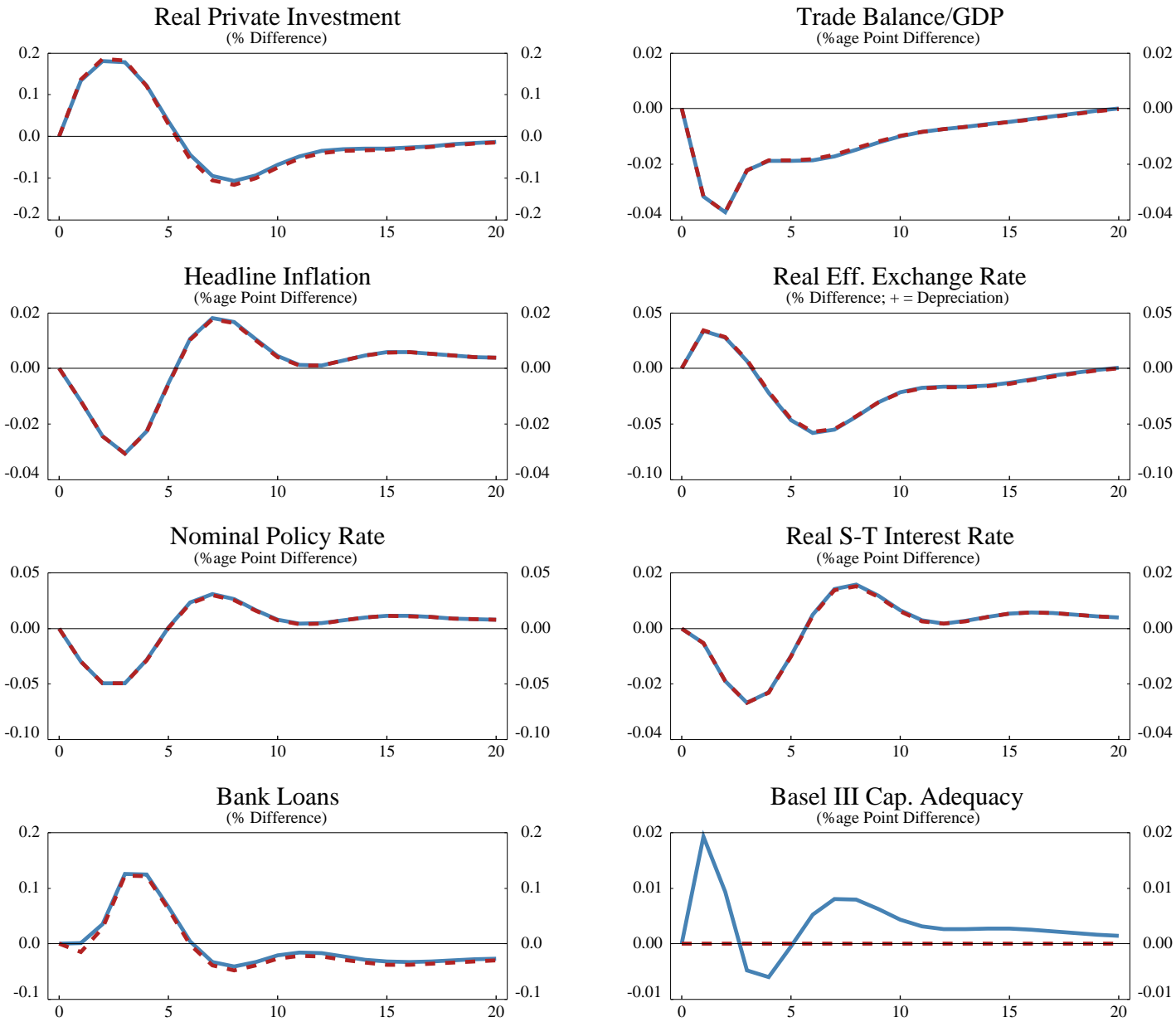

External Financing Spread

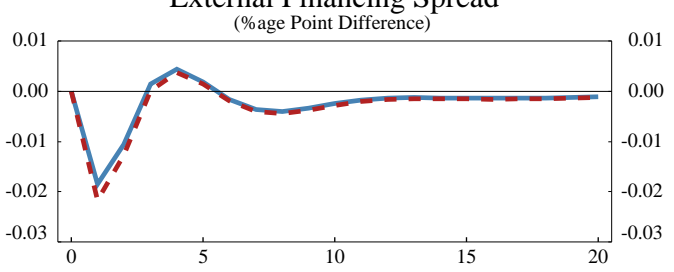

Regulatory Lending Spread

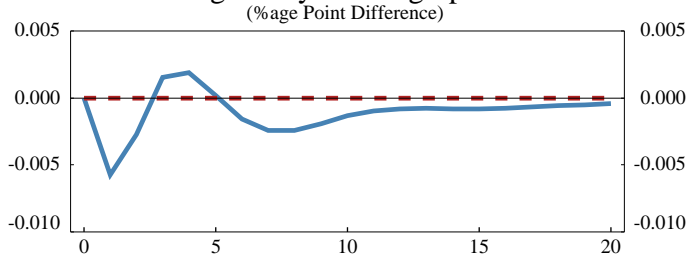


Figure 8. Temporary Stimulus Through Lower Capital Income Taxes (1pc of GDP for 2 years)

Percent or percentage point deviation from steady-state baseline (Horizontal axis is in years)
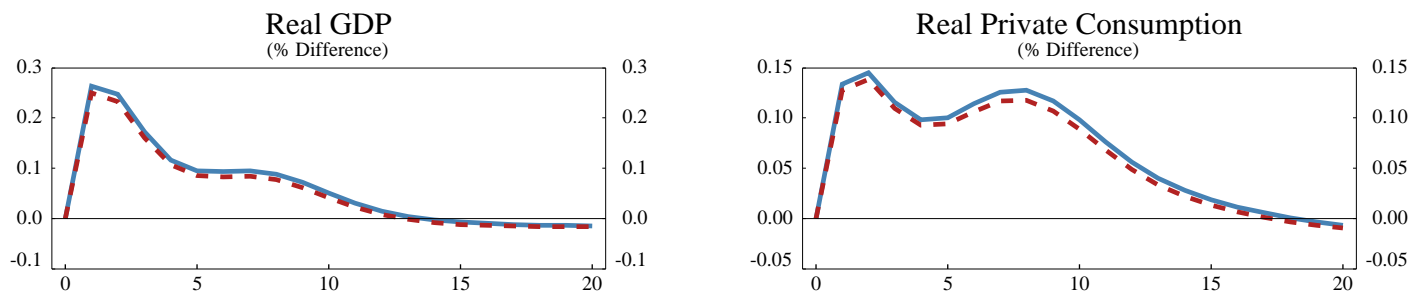

Real Private Investment
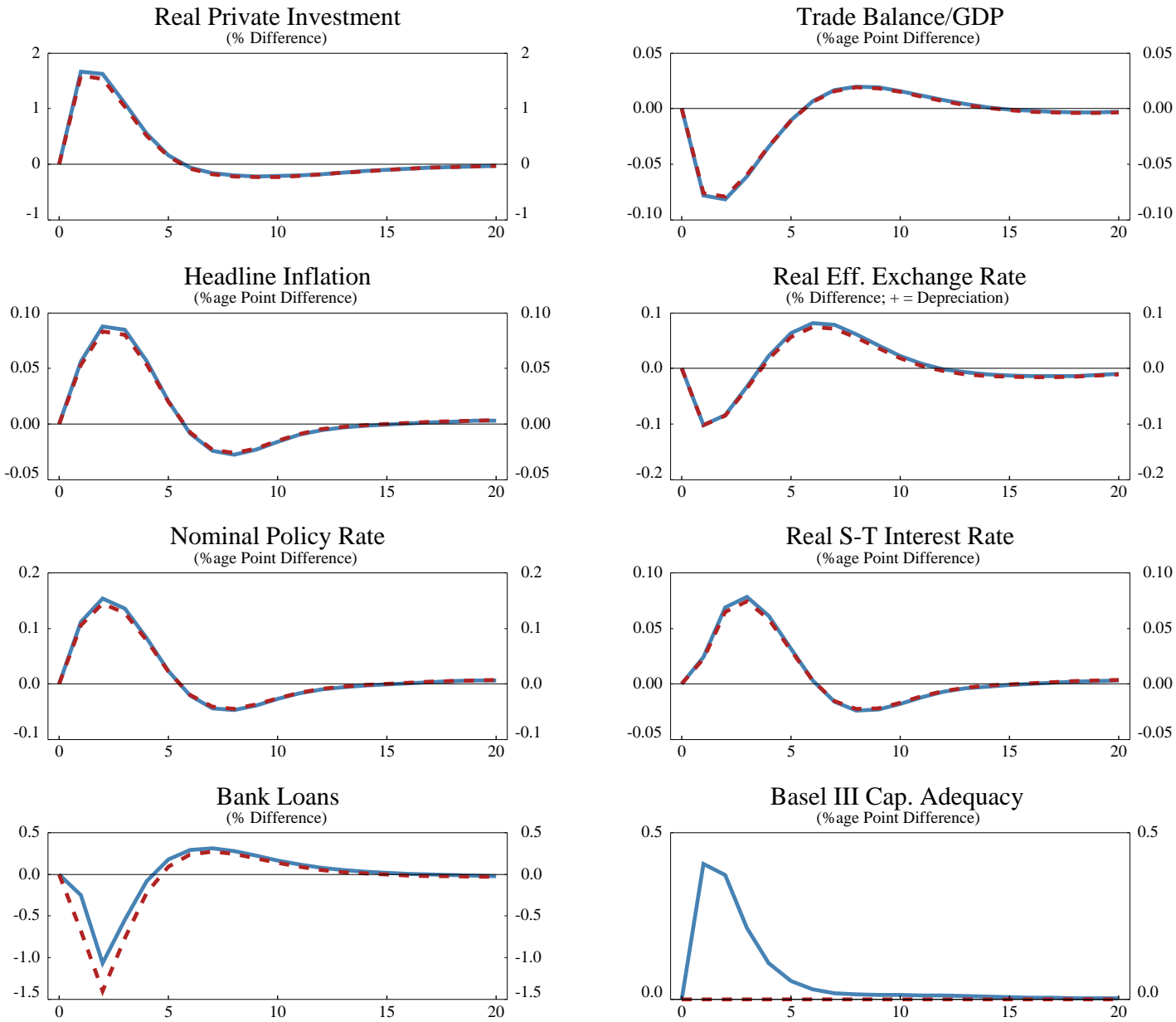

External Financing Spread

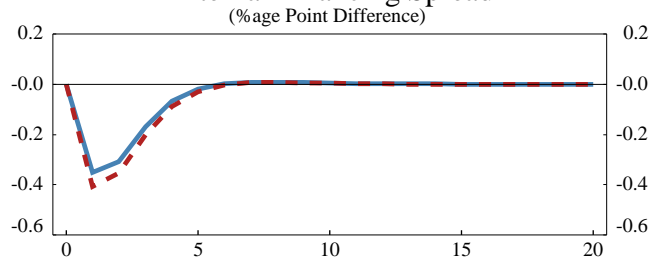

Regulatory Lending Spread

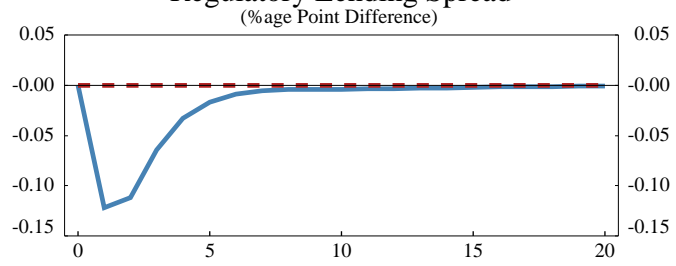




\section{Figure 9. Temporary Increase in the Policy Rate}

Percent or percentage point deviation from steady-state baseline

(Horizontal axis is in years)

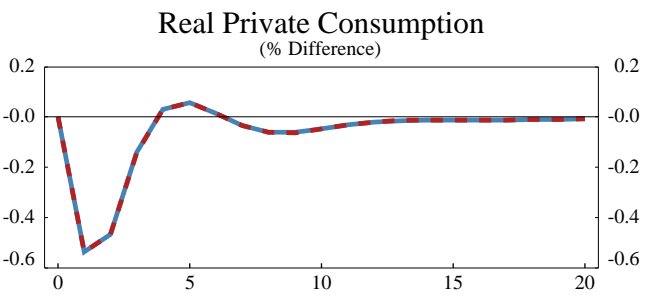

Real Private Investment (\% Difference)
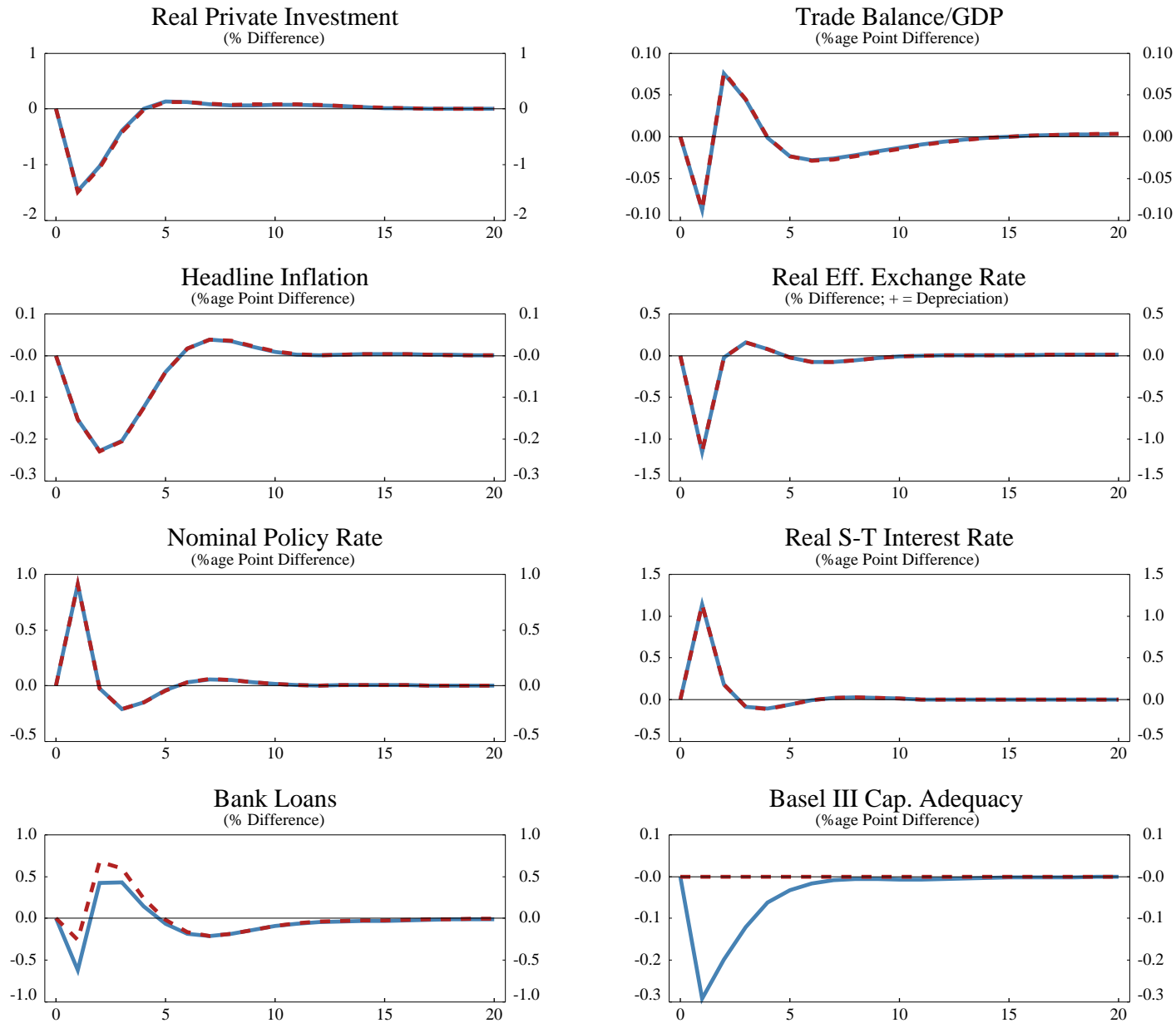

External Financing Spread

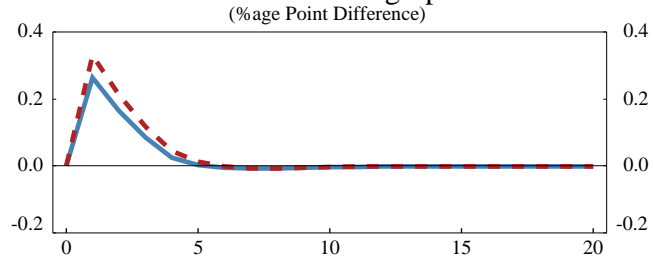

Regulatory Lending Spread

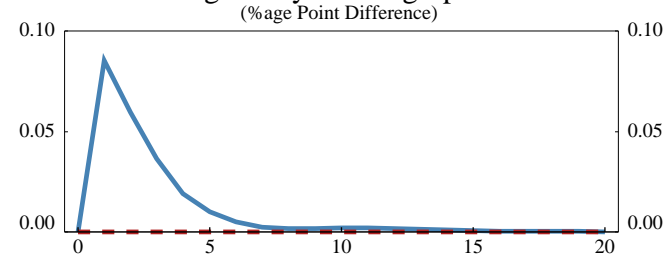


Figure 10. Temporary Increase in Private Domestic Demand

Percent or percentage point deviation from steady-state baseline

(Horizontal axis is in years)

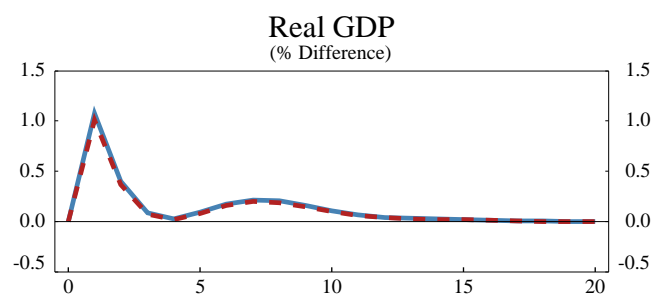

Real Private Investment

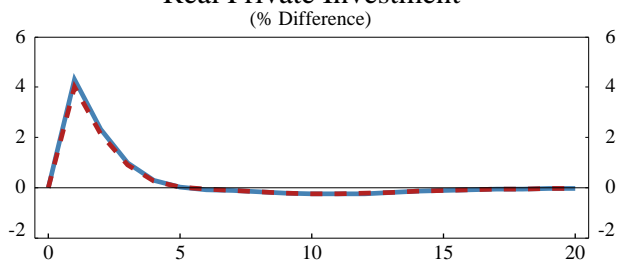

$\underset{\text { (\%age Point Difference) }}{\text { Headline Inflation }}$

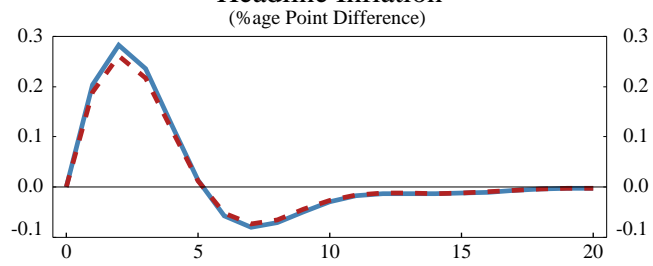

Nominal Policy Rate
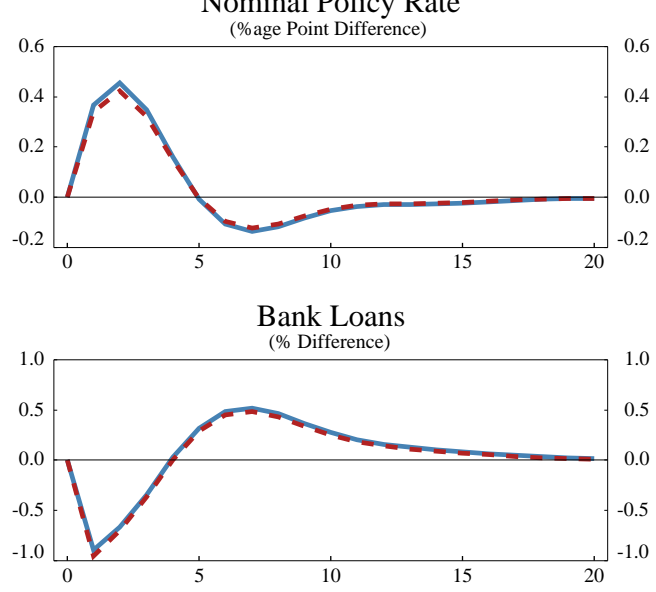

External Financing Spread

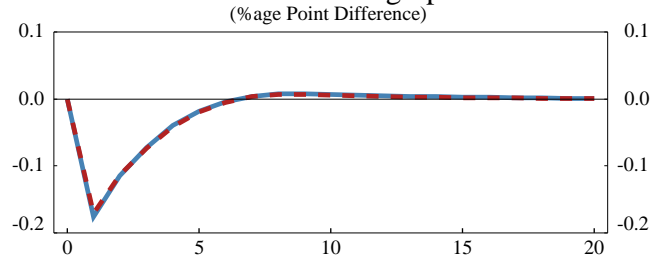

Real Private Consumption
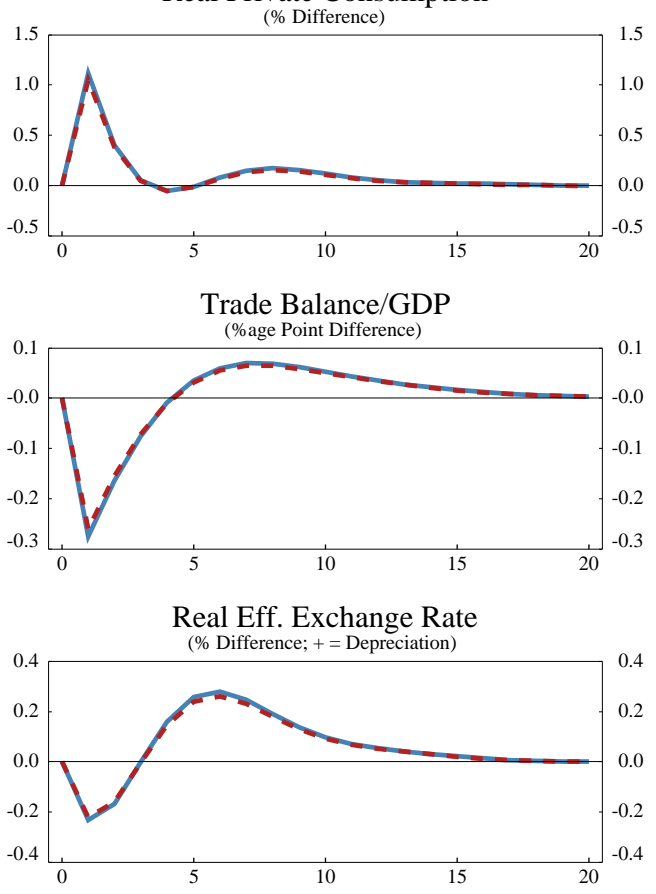

Real S-T Interest Rate

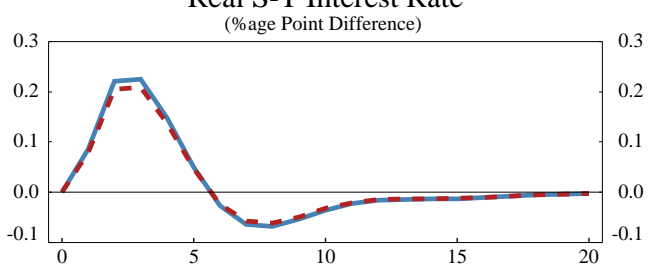

Basel III Cap. Adequacy

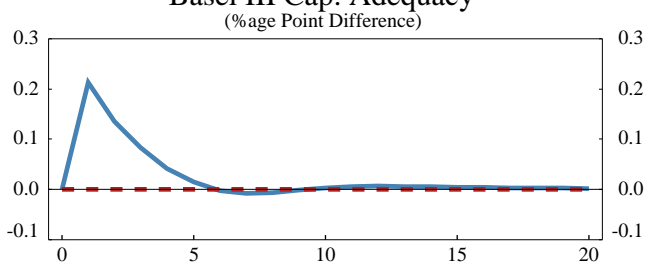

Regulatory Lending Spread

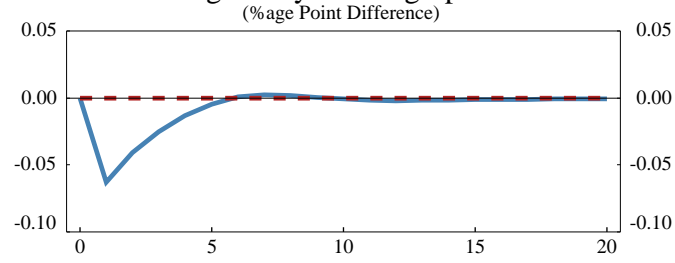




\section{Figure 11. Permanent Increase in Labor Productivity}

Percent or percentage point deviation from steady-state baseline

(Horizontal axis is in years)

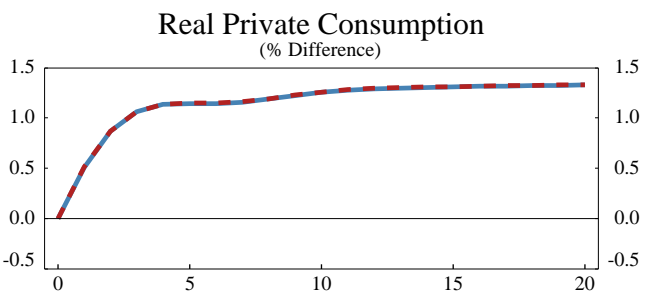

Real Private Investment (\% Difference)
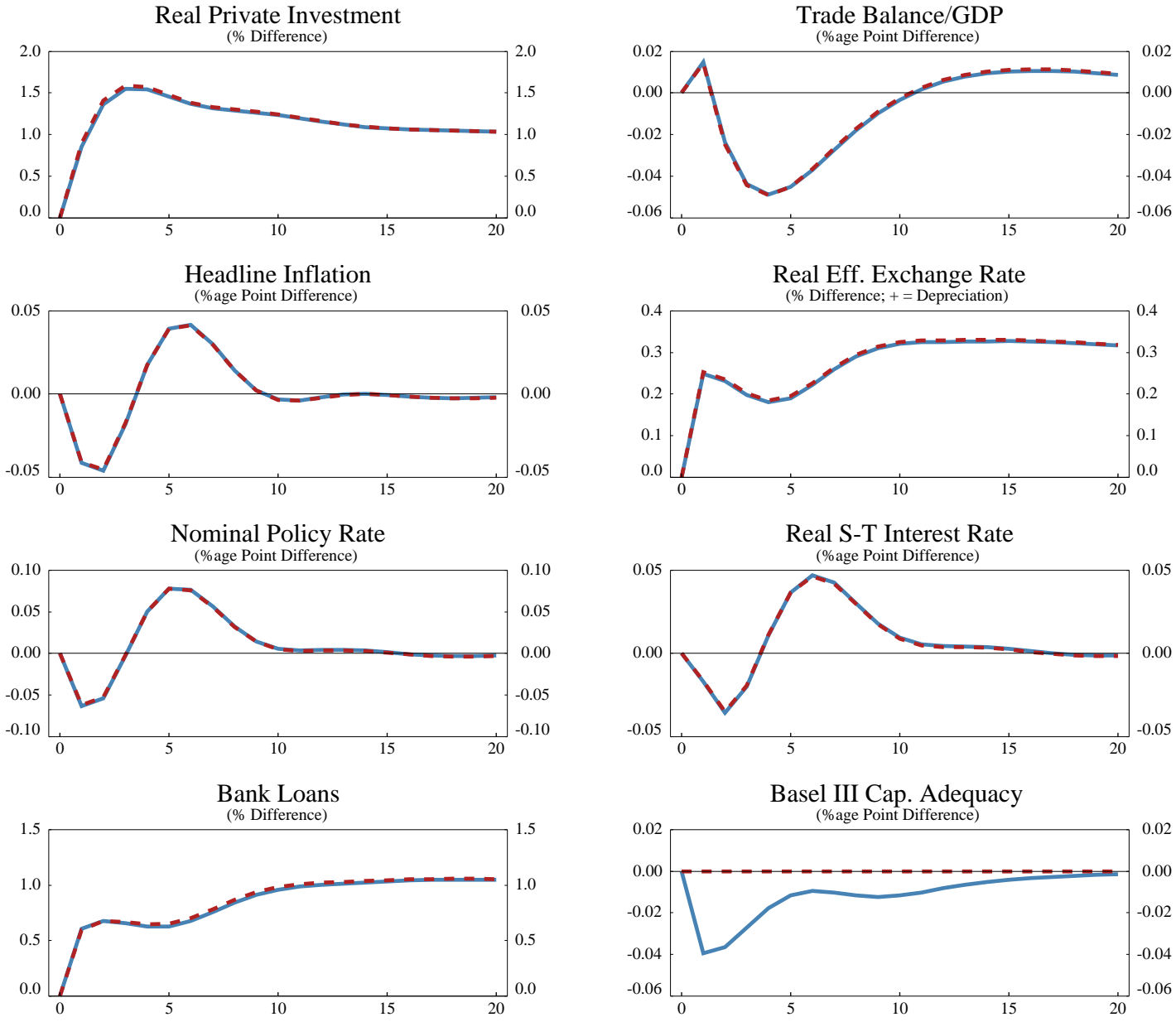

External Financing Spread

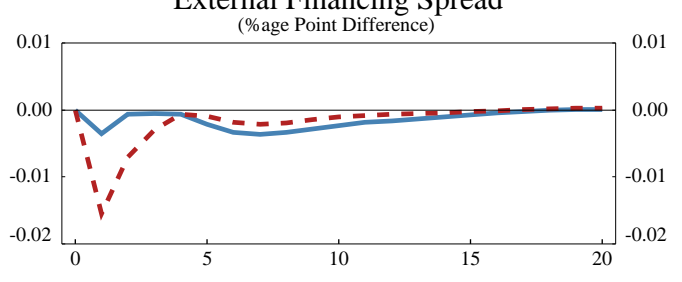

Regulatory Lending Spread

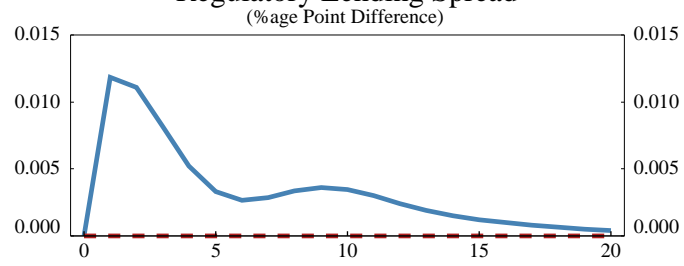


Figure 12. Ten-Year Increase in Labor Productivity Growth

Percent or percentage point deviation from steady-state baseline (Horizontal axis is in years)

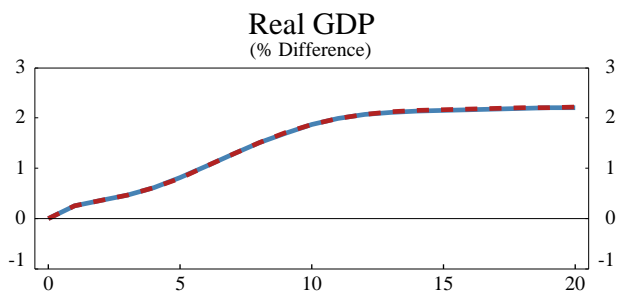

Real Private Investment
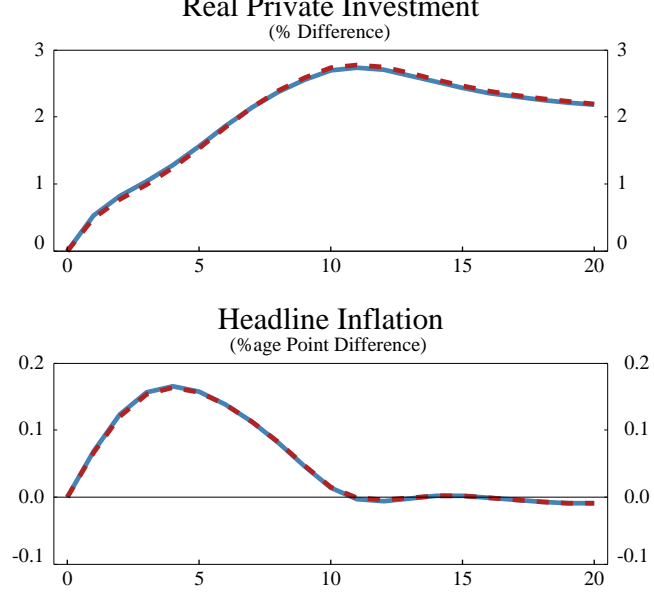

Nominal Policy Rate
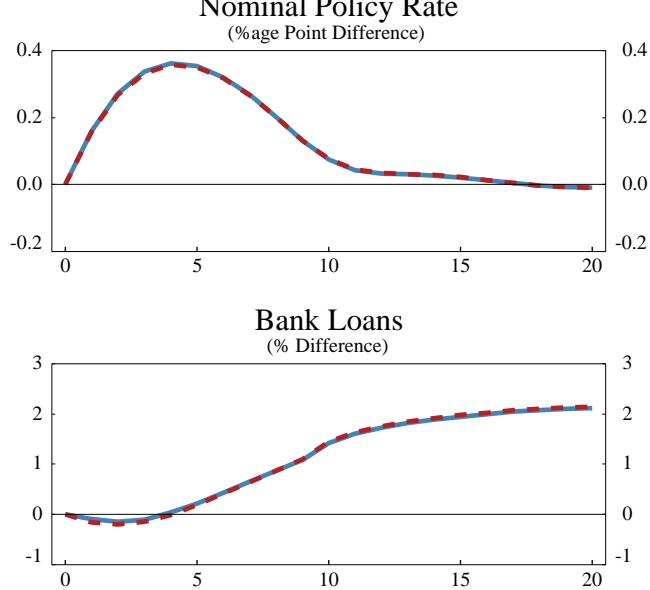

External Financing Spread

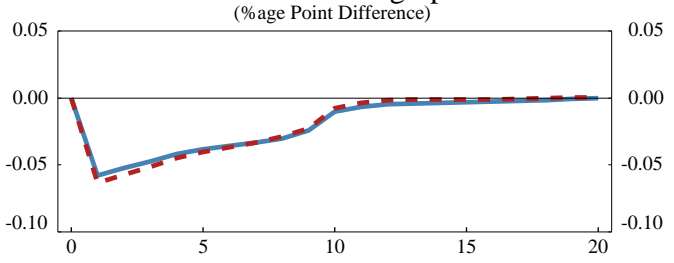

Real Private Consumption

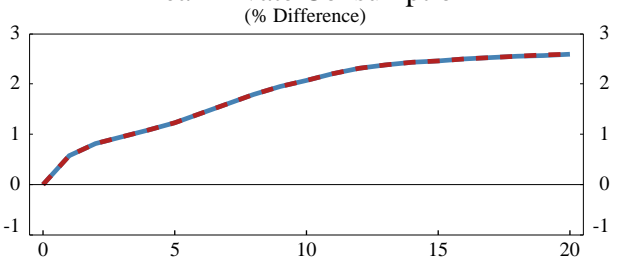

Trade Balance/GDP

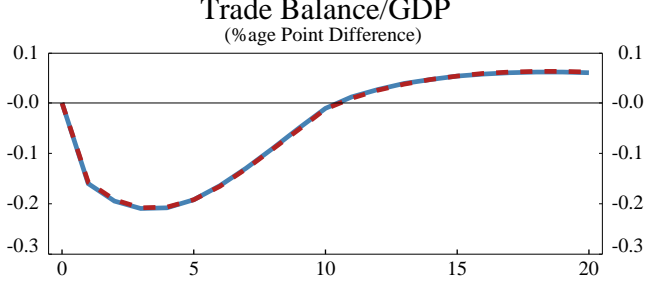

Real Eff. Exchange Rate

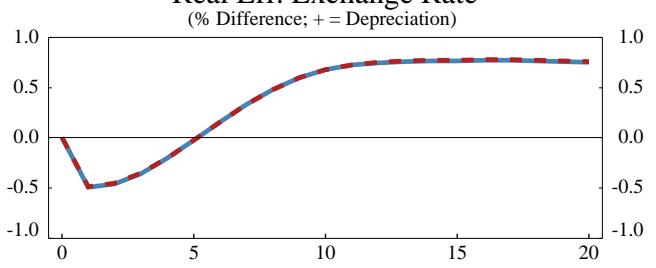

Real S-T Interest Rate

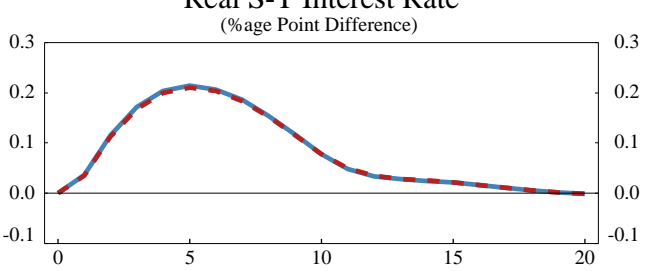

Basel III Cap. Adequacy

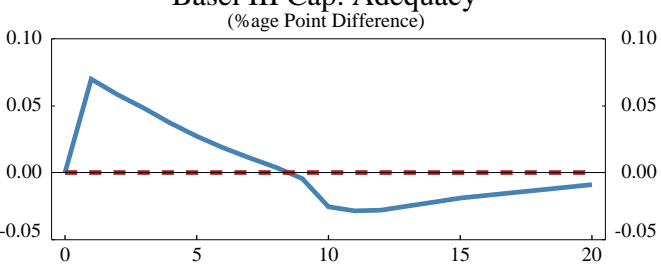

Regulatory Lending Spread

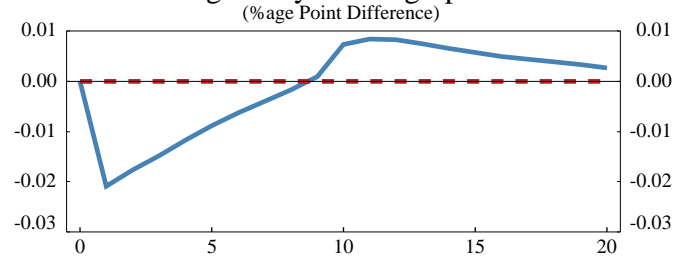




\section{Figure 13. Permanent Drop in Wage Markup}

Percent or percentage point deviation from steady-state baseline (Horizontal axis is in years)

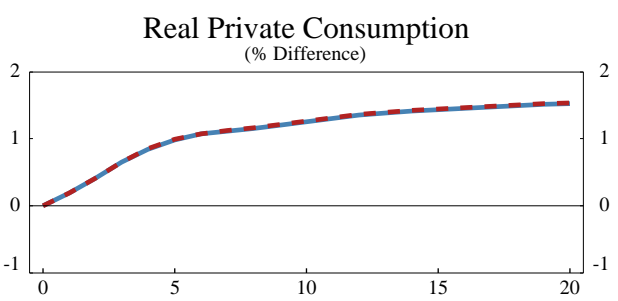

Real Private Investment
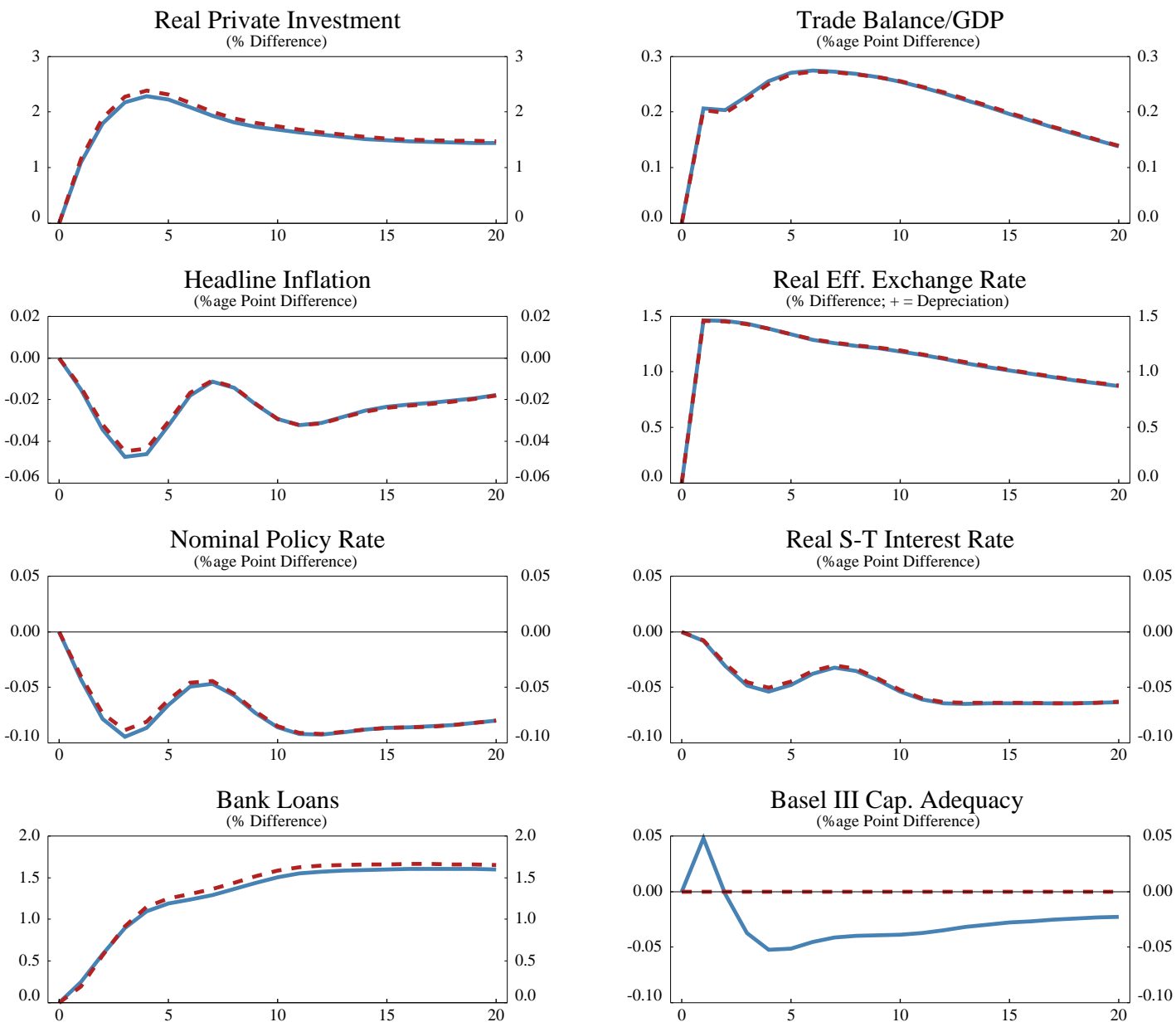

External Financing Spread

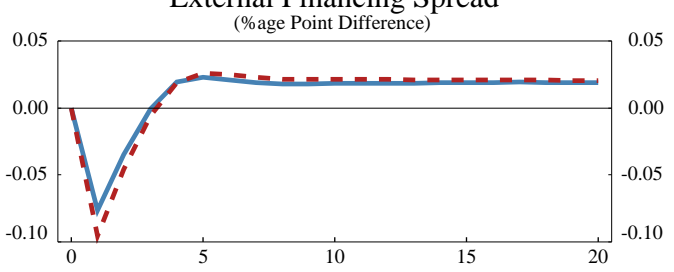

Regulatory Lending Spread

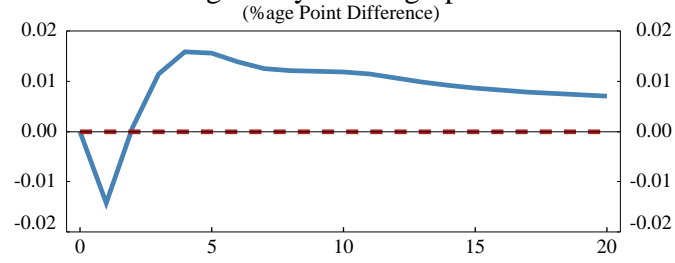




\section{Figure 14. Permanent Drop in Price Markup}

Percent or percentage point deviation from steady-state baseline (Horizontal axis is in years)

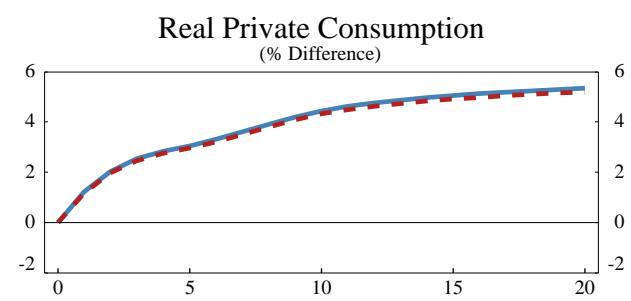

Real Private Investment
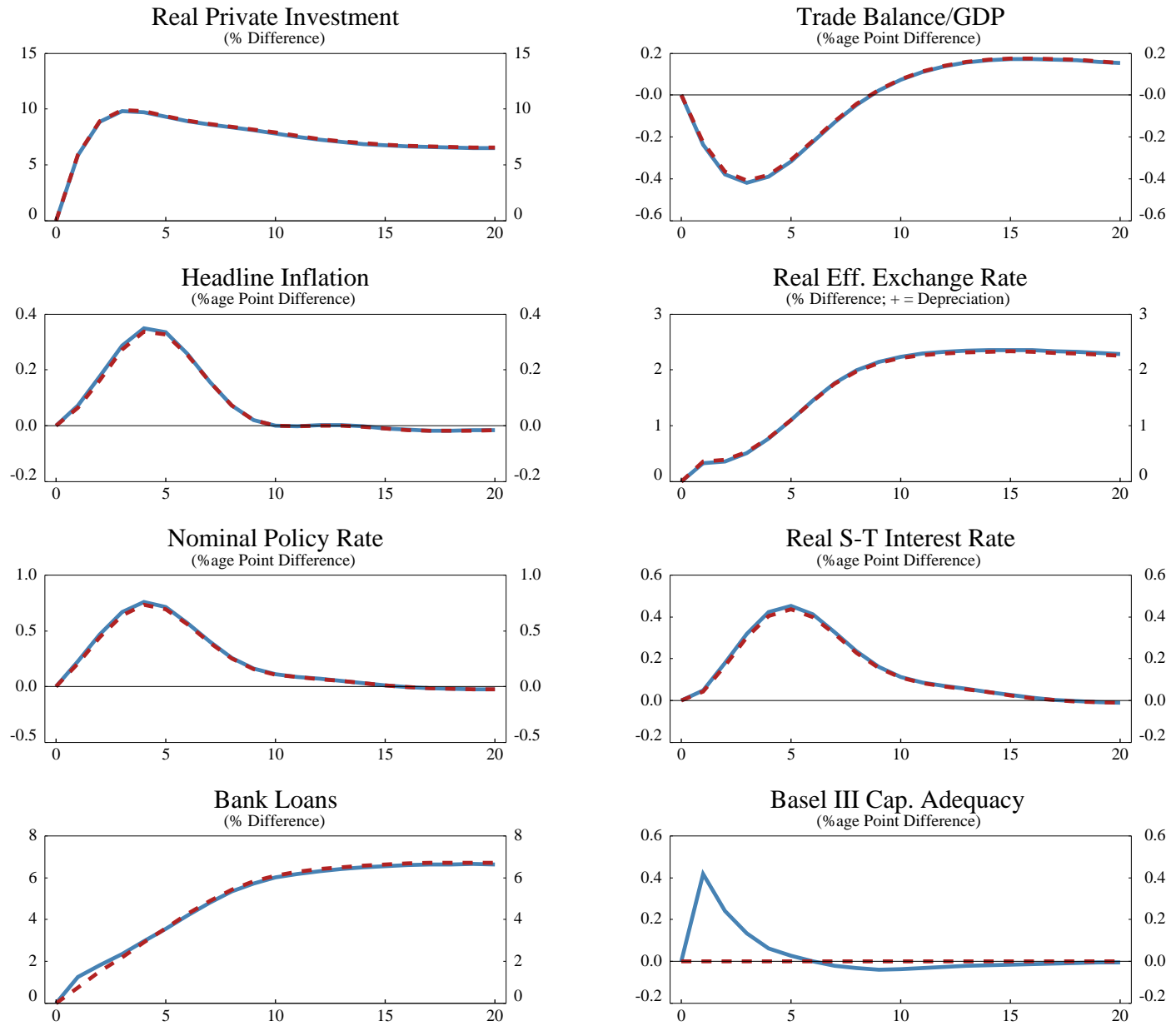

Basel III Cap. Adequacy

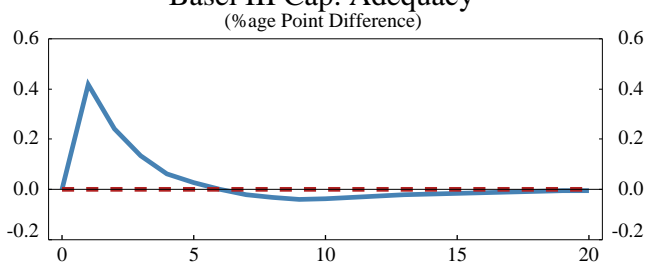

External Financing Spread

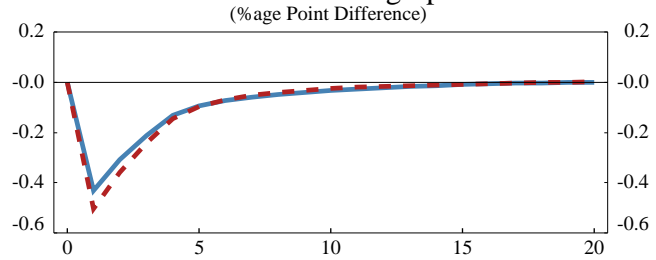

Regulatory Lending Spread

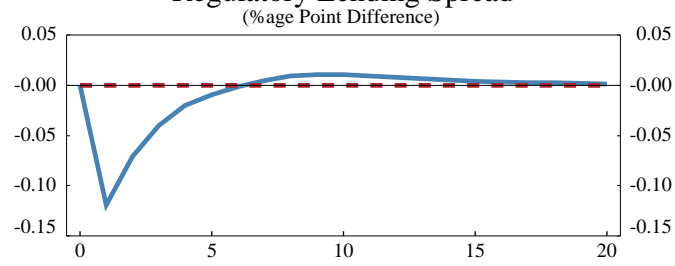




\section{Figure 15. Permanent Increase in Tariffs}

Percent or percentage point deviation from steady-state baseline (Horizontal axis is in years)

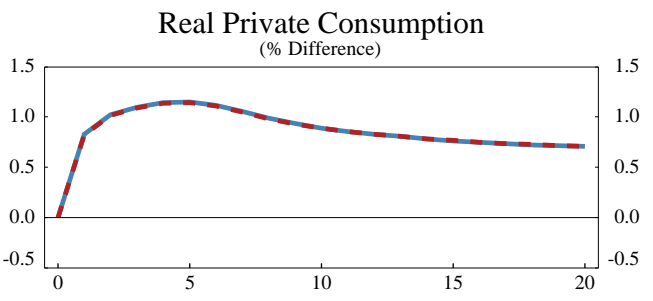

Real Private Investment (\% Difference)
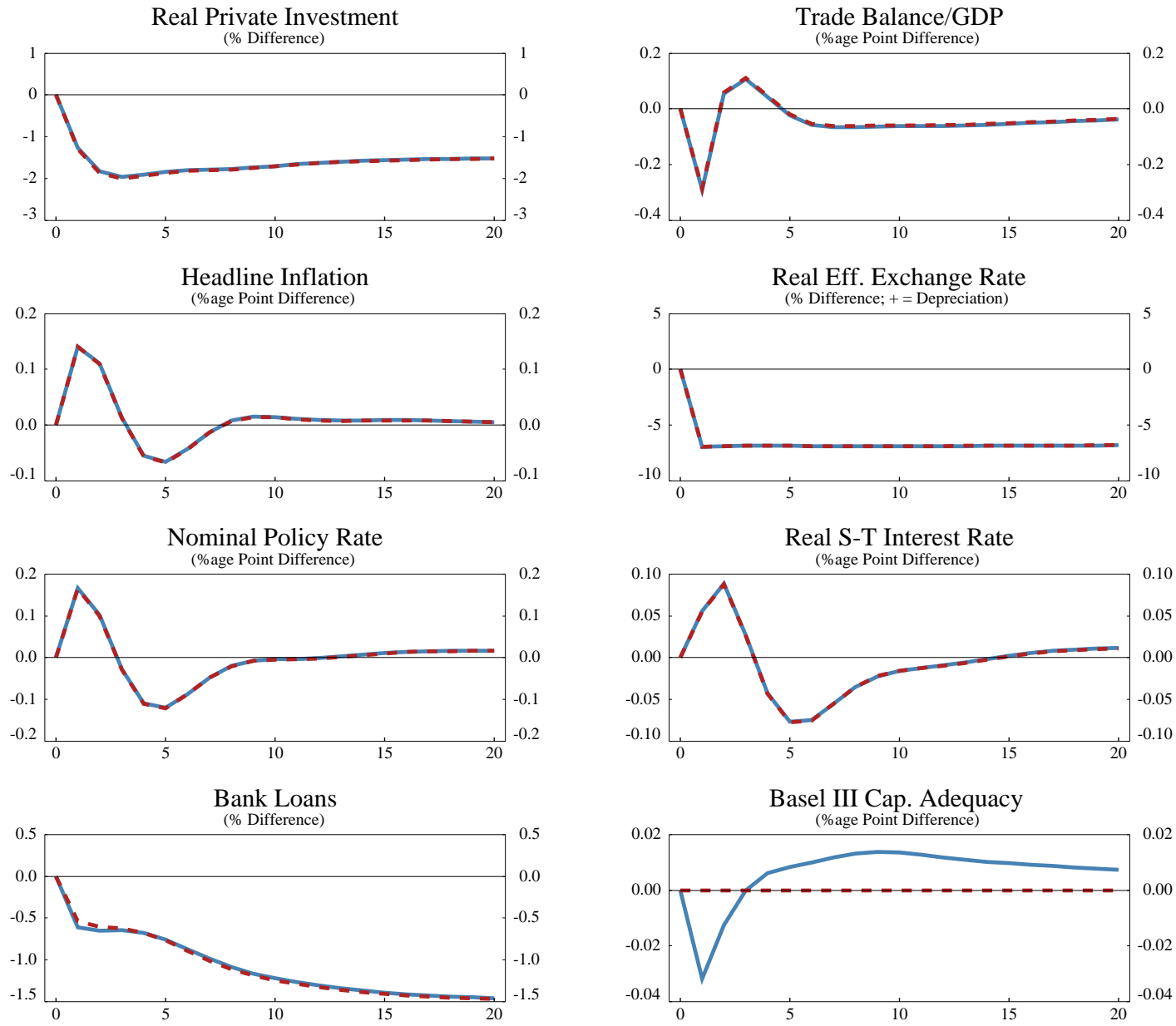

External Financing Spread

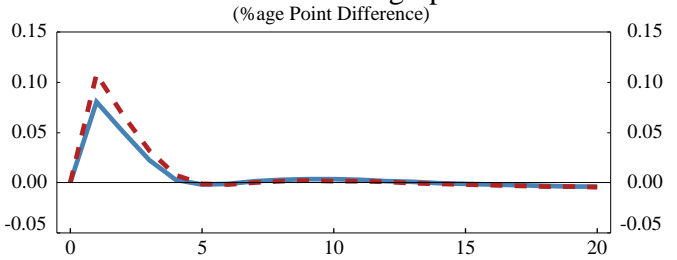

Regulatory Lending Spread

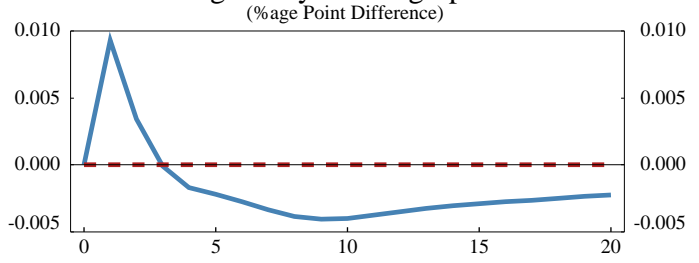


Figure 16. Temporary Increase in Borrower Riskiness - Equal External Financing Spreads

Percent or percentage point deviation from steady-state baseline (Horizontal axis is in years)

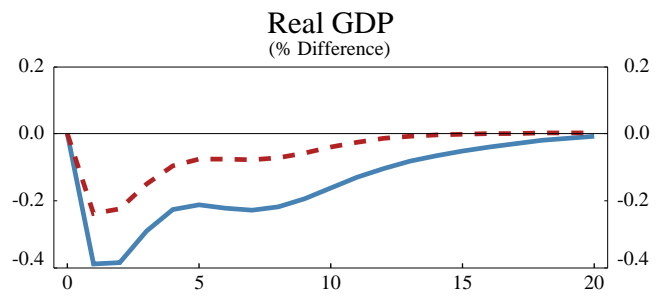

Real Private Investment
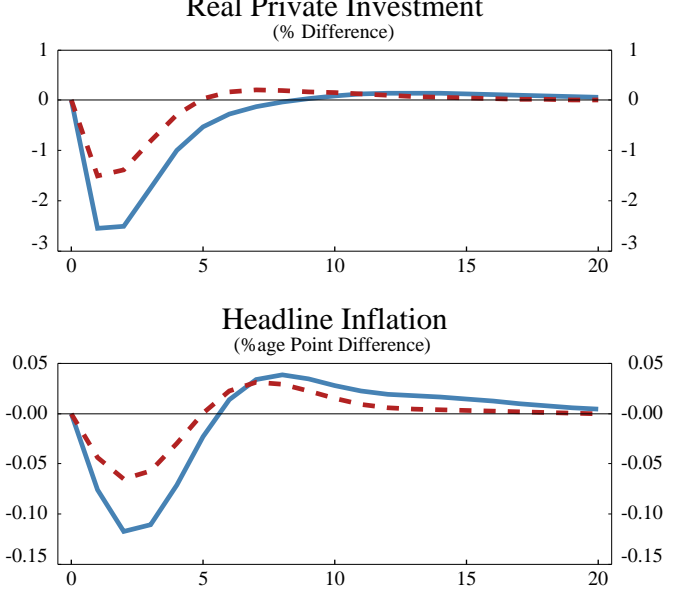

Nominal Policy Rate
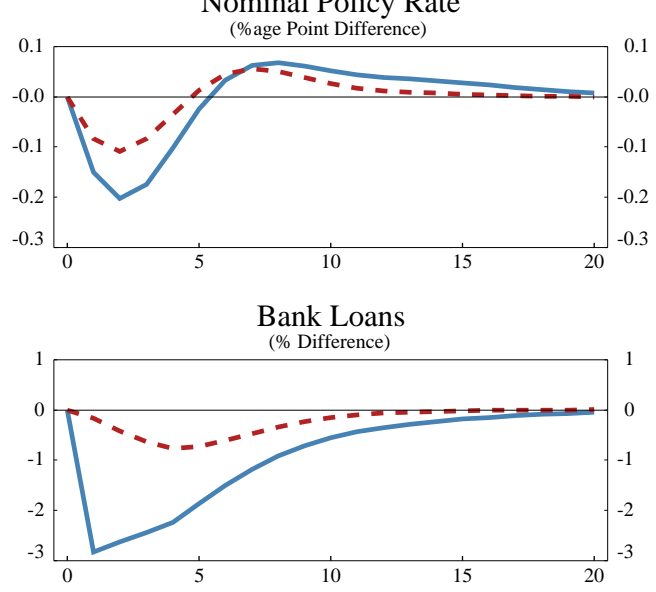

External Financing Spread

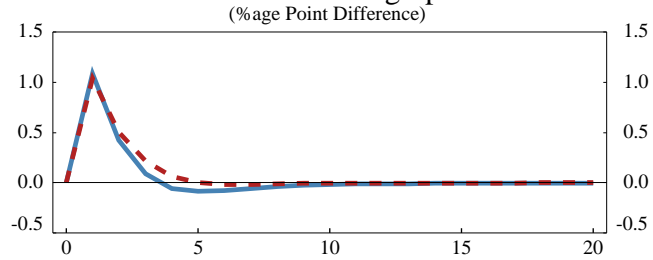

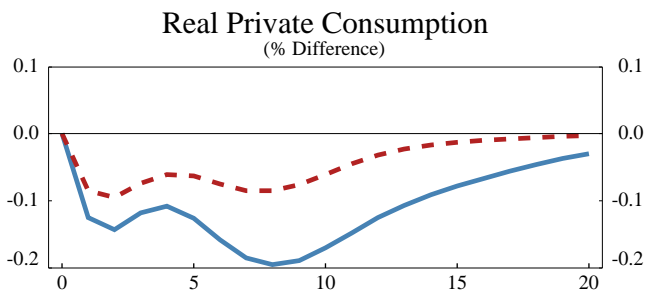
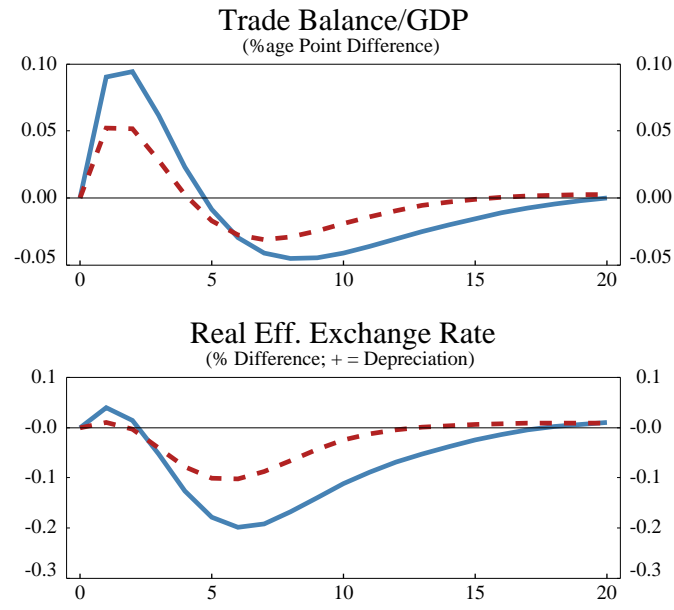

Real S-T Interest Rate

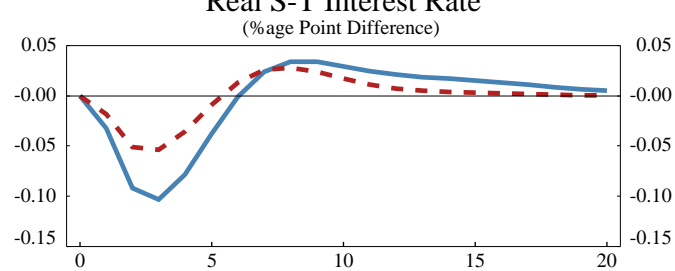

Basel III Cap. Adequacy

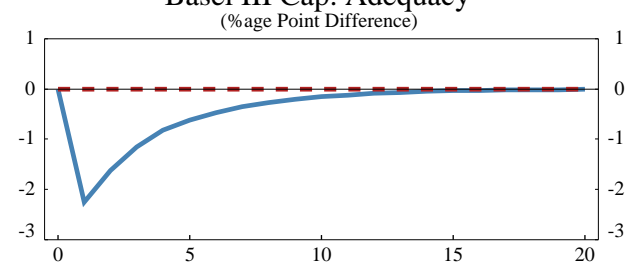

Regulatory Lending Spread

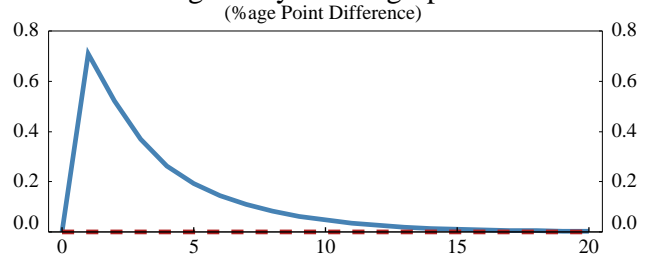


Figure 17. Temporary Increase in Borrower Riskiness - Bank Loan Losses

$\frac{\Lambda_{t}^{\ell}}{\overline{g d p}}$

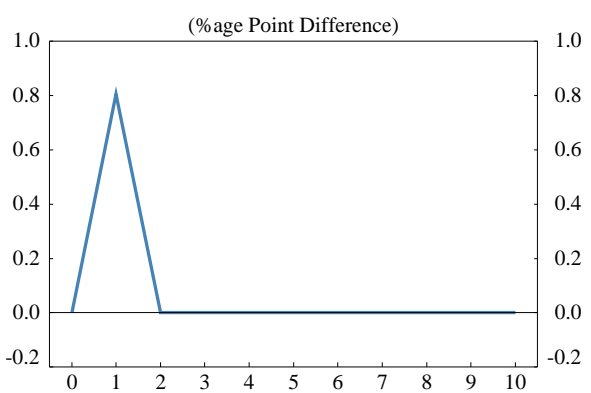

$\frac{r_{\ell, t} \check{\ell}_{t-1}}{\overline{g d p}}$

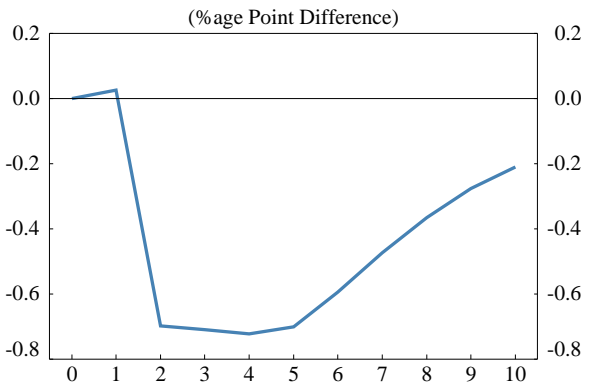

$\frac{q_{t-1} \breve{k}_{t-1} r e t_{k, t} \bar{\gamma}}{\overline{g d p}}$

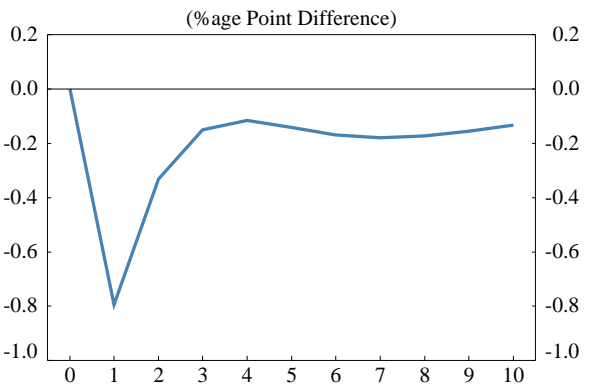

$\frac{\Lambda_{t}^{\ell}}{\bar{\ell}}$

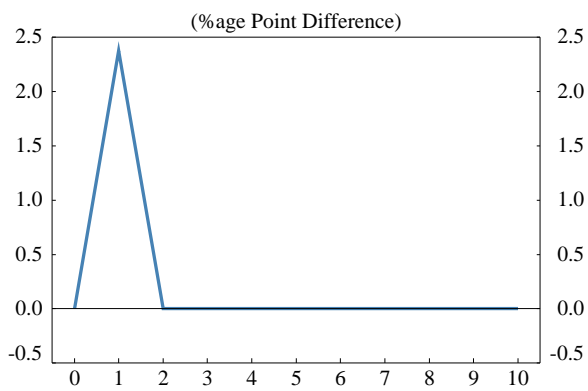

$\frac{q_{t-1} \check{k}_{t-1} r e t_{k, t} \gamma_{t}}{\overline{g d p}}$

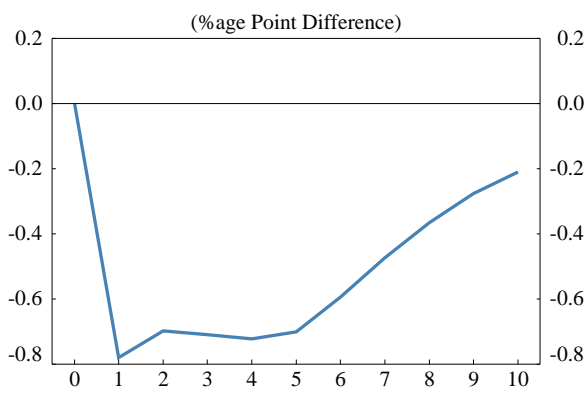

$\frac{q_{t-1} \breve{k}_{t-1} \overline{r e t_{k}} \gamma_{t}}{\overline{g d p}}$

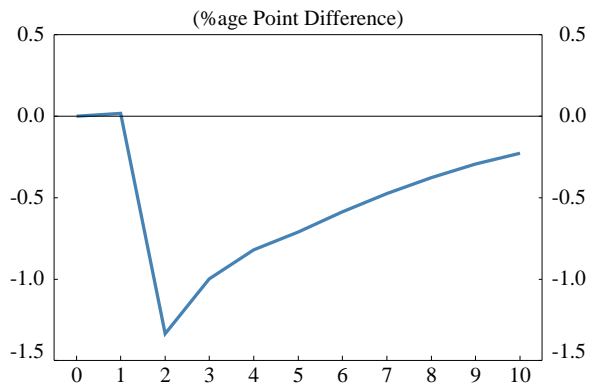


Figure 18. Temporary Increase in Borrower Riskiness - Equal Shock Sizes

Percent or percentage point deviation from steady-state baseline (Horizontal axis is in years)

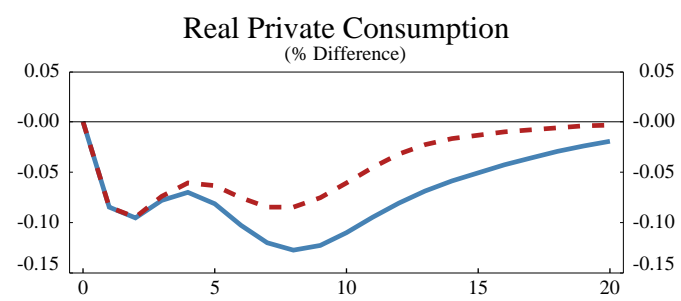

Real Private Investment
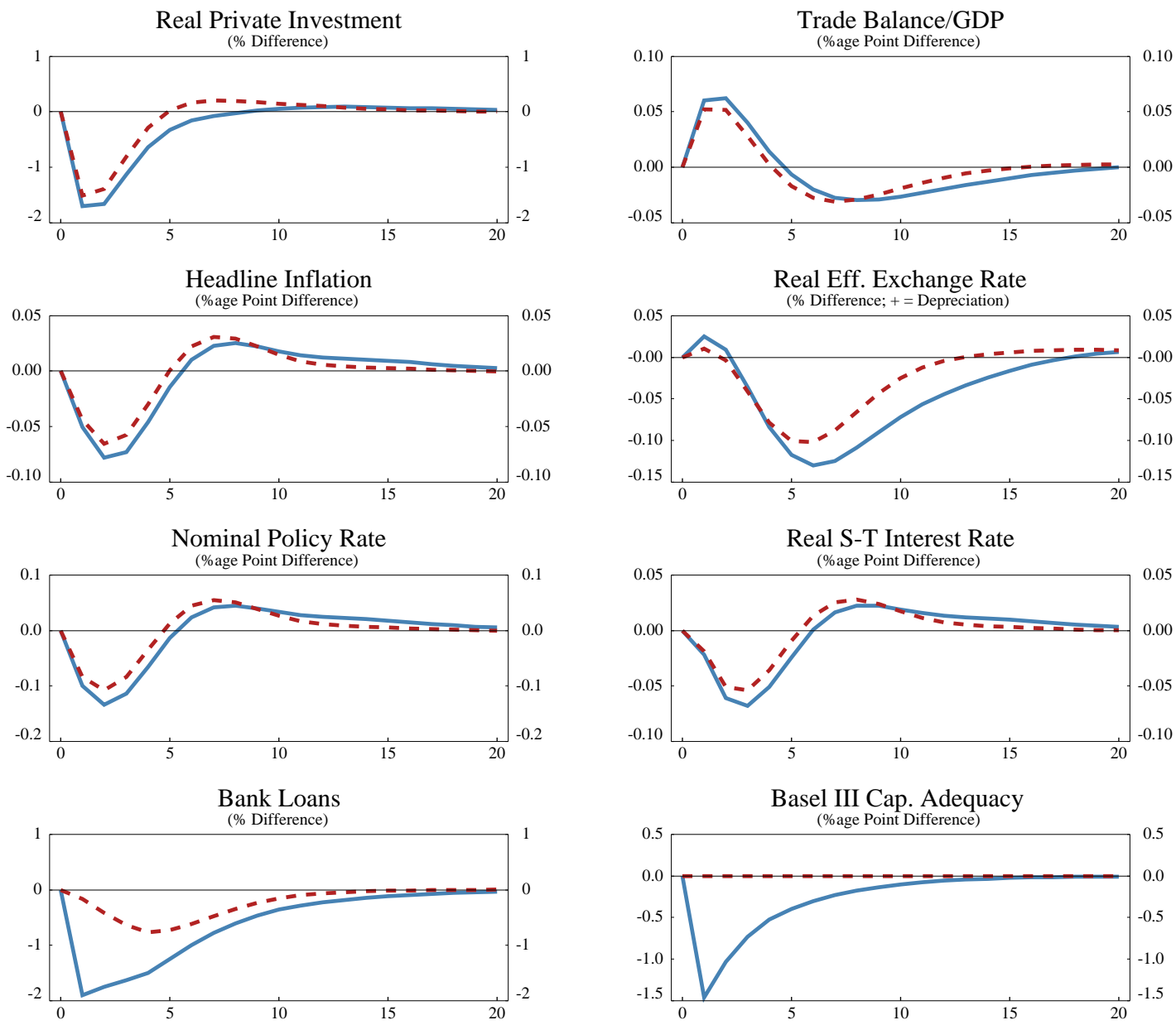

Basel III Cap. Adequacy

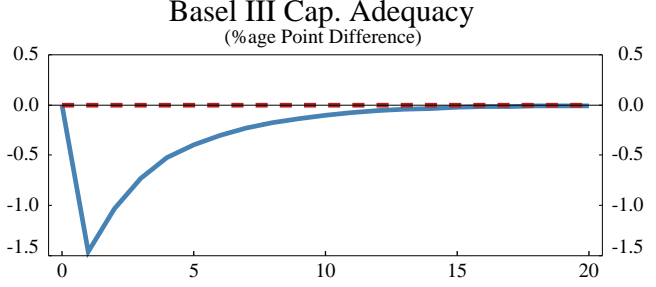

External Financing Spread

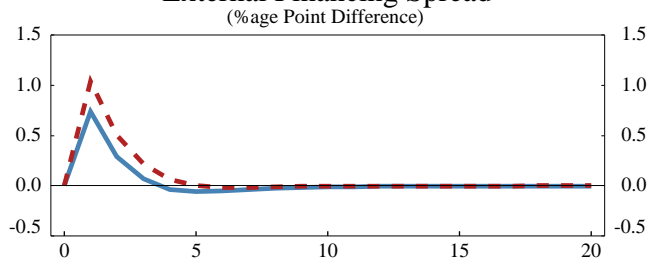

Regulatory Lending Spread

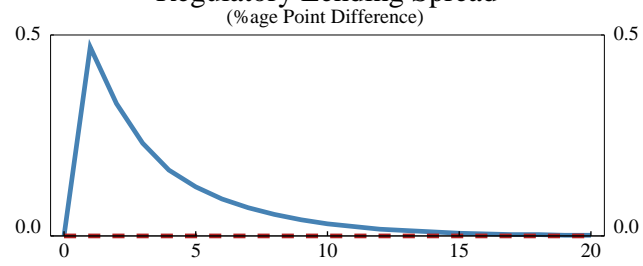




\section{Figure 19. Fixed versus Countercyclical MCAR}

Percent or percentage point deviation from steady-state baseline Horizontal axis is in years)

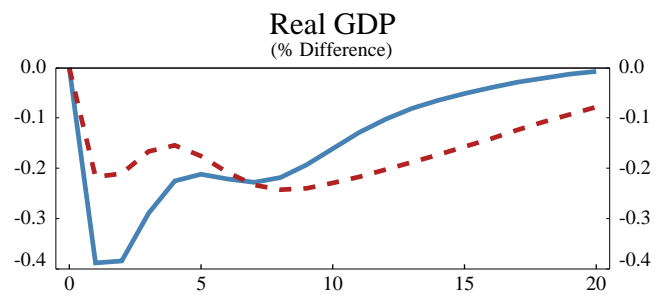

Real Private Investment
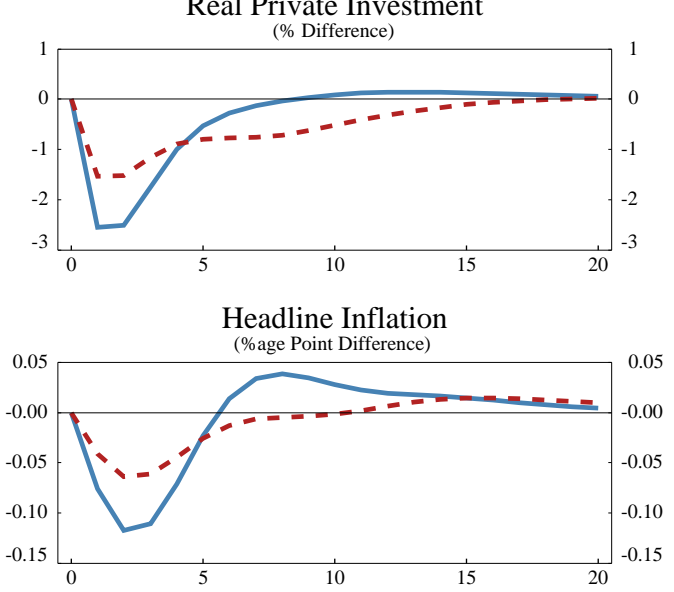

Nominal Policy Rate
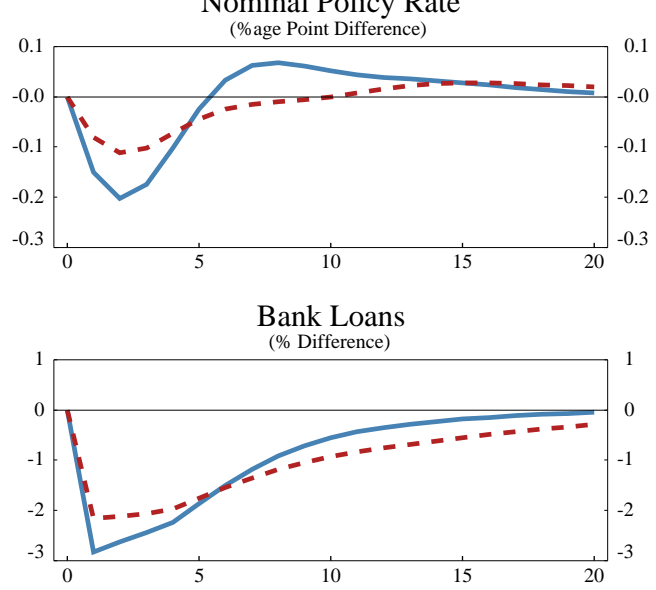

External Financing Spread

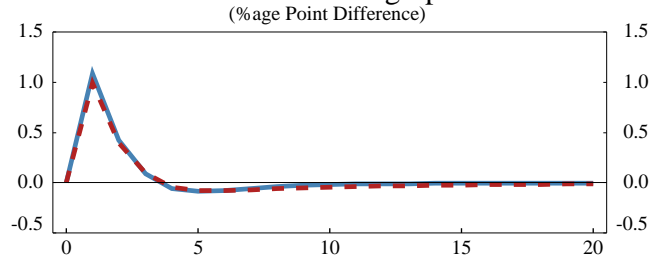

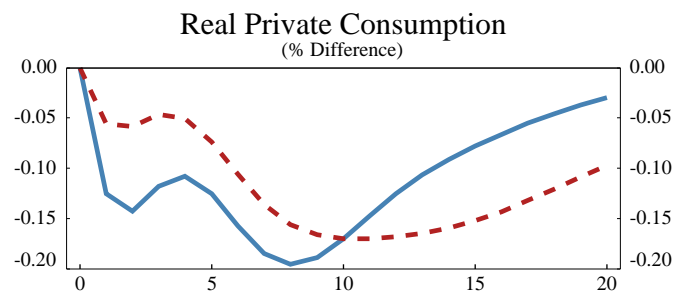
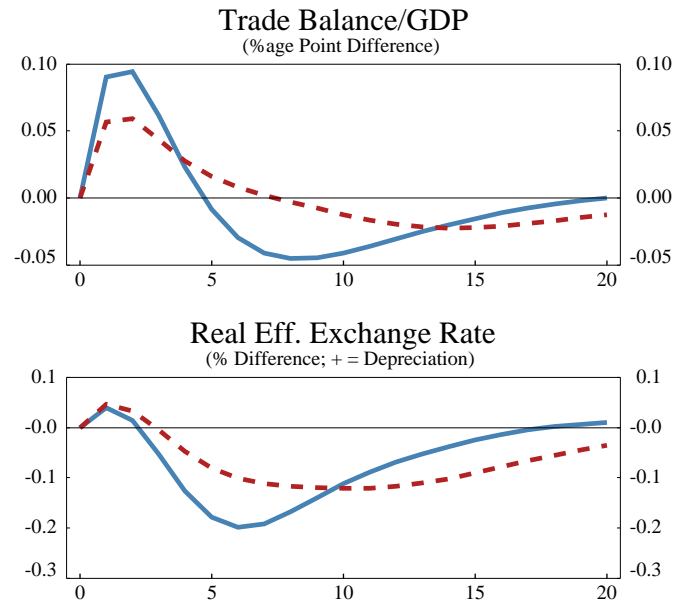

Real S-T Interest Rate

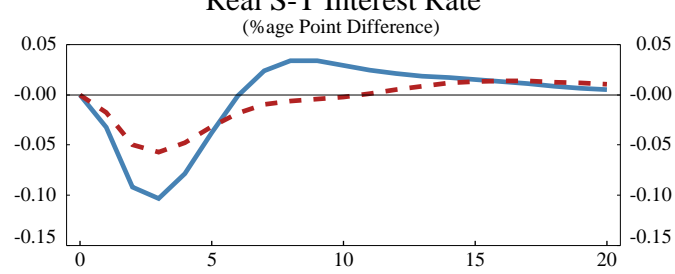

Basel III Cap. Adequacy

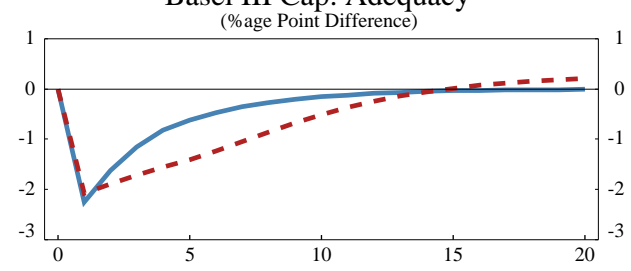

Regulatory Lending Spread

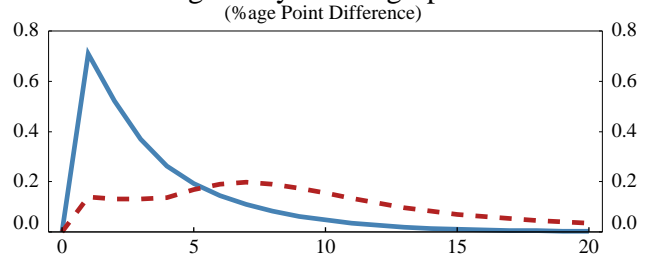




\section{Figure 20. Immediate versus Gradual Increase in MCAR}

Percent or percentage point deviation from steady-state baseline (Horizontal axis is in years)
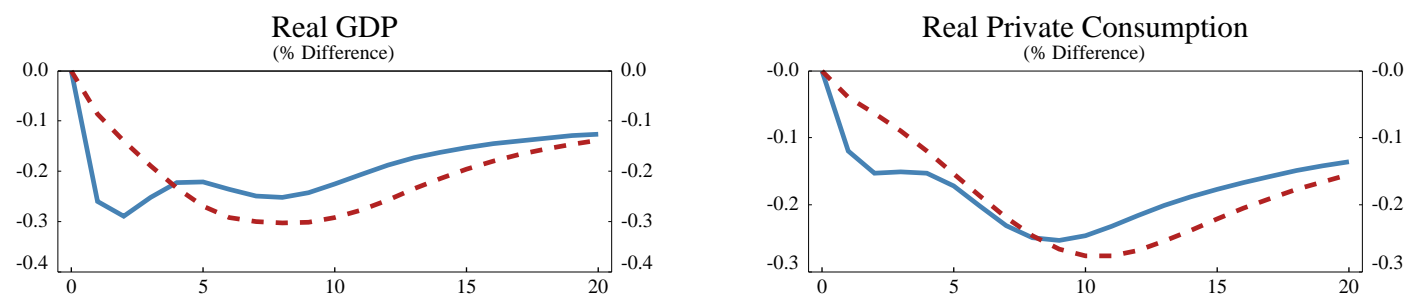

Real Private Investment
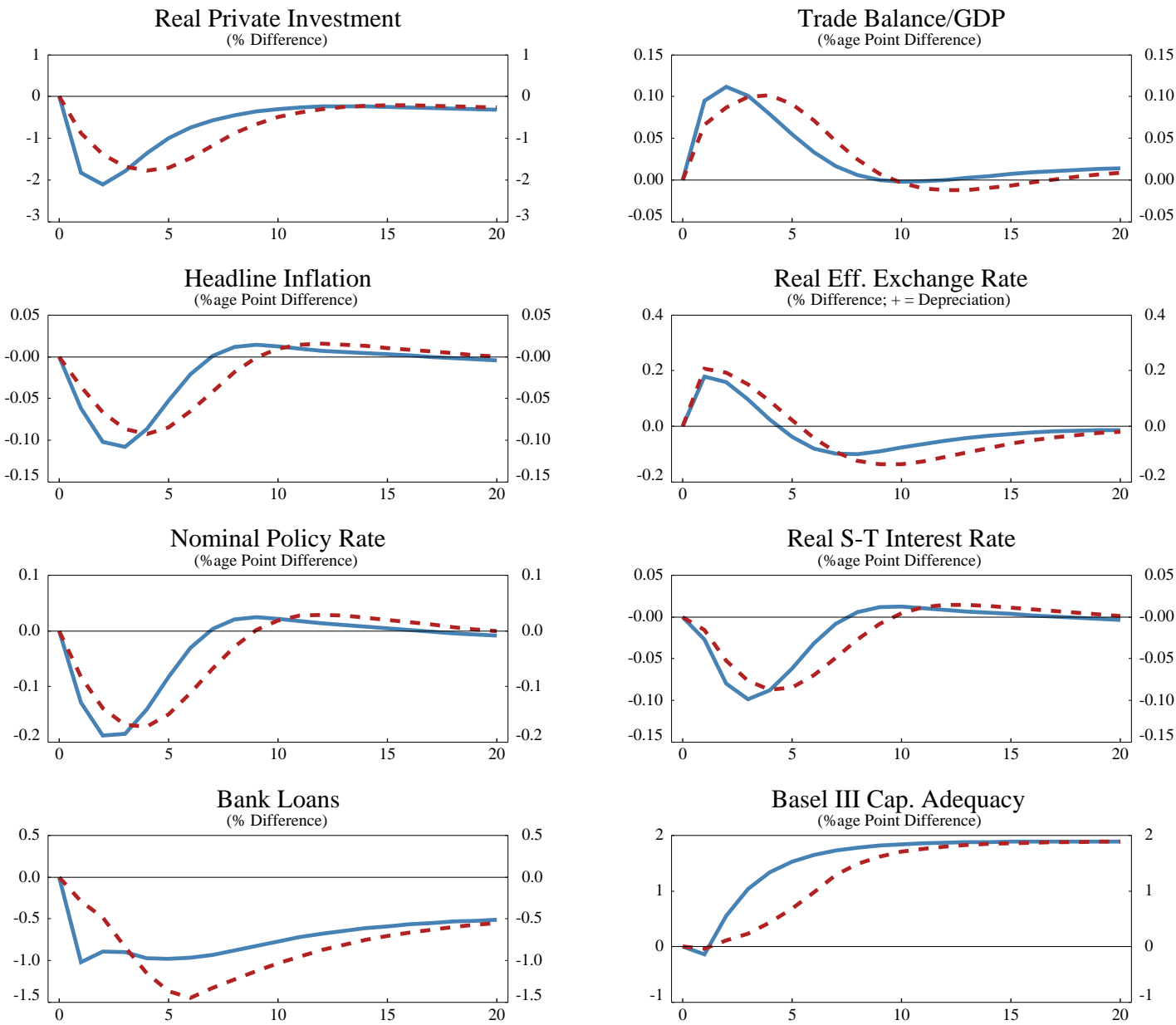

Basel III Cap. Adequacy

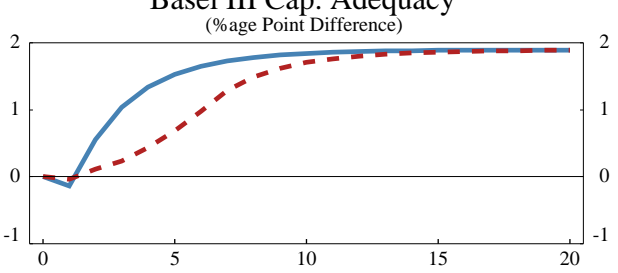

External Financing Spread

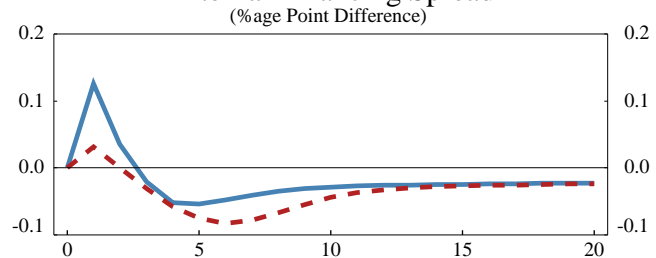

Regulatory Lending Spread

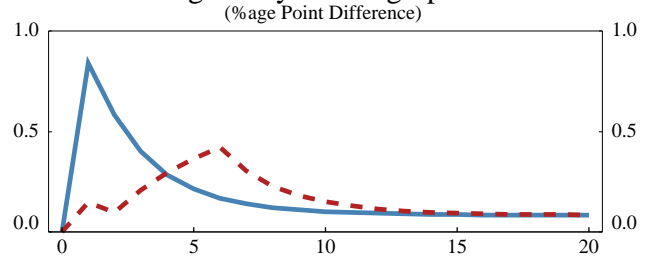

